\title{
DOCUMENTOS
}

\section{Cartas de Julio Saavedra Molina a Dorothy Clotelle Clarke}

I

\author{
Santo Domingo $2 \mathrm{I} 27$ \\ Santiago de Chile, \\ I6 Octubre I938.
}

Muy respetada señorita:

Su amable respuesta del ig de Septiembre está en mi poder, como asimismo su valioso obsequio: Bibliografia, Sobre la quintilla, Tiercet Rimes..., y $A$ Note on the Décima..., todo lo cual he leído ávidamente y por lo que le doy infinitas gracias.

Lamento que sus otras obras le haya sido imposible enviármelas: no las conozco y, a juzgar por las que he recibido, han de ser valiosas. Su averiguación sobre las rimas preferidas por los clásicos en el soneto es interesante, como también lo que dice acerca de la quintilla y de la espinela. De su Bibliografía hablo en hoja aparte, cuyo original envío a don Federico de Onís para que se publique en la "Revista Hispánica Moderna" (Casa de las Españas, Columbia University), quien me ha pedido colaboraciones para ella.

Tampoco conozco las obras del profesor Morley, a quien enviaré pronto mis folletos, por intermedio de usted. Van en paquete certificado.

Por este correo o por el próximo le enviaré un folleto que se está 
terminando de imprimir: Poesias y Prosas naras de Rubén Dario, que he compilado y anotado.

De los tratados sobre versificación italiana que menciona en la p. 380 , nota 8 de Tiercet Rimes, no conozco los de Casini, Guarnerio ni Federzoni. Mucho le agradecería si me dijese cuál de ellos trata la materia o materias fundamentales (ritmo, pies, sílabas, tiempo, altura, intensidad, medida, etc.) con hondura y precisión, desde un punto de vista italiano. Busco eso y no lo encuentro.

Tendría el mayor agrado en poderle corresponder con datos que a usted le faltasen.

En mi reseña sobre su Bibliografía no quise mencionar dos artículos de revistas tocantes a mis opúsculos:

La garra del león. Crítica desorientada. En "Arte", revista que dirige en Ibagué, Colombia, don Manuel Antonio Bonilla. Núm. de Mayo-Julio de 1936, pp. 943-949. Firmado: Guillermo Valencia, el poeta bien conocido. Es una respuesta al artículo "Crítica literaria", publicado por autor anónimo, según parece, en que éste toma pretexto de mi estudio sobre los hexámetros para atacar a Valencia, y el poeta dice cuál fue su técnica al componer A Popayán. Menciona al Dr. C. Molina Garcés, pero no coincide con él en la explicación.

A propos de l'Alexandrin dans la Poésie espagnole. En "Revue de l'Enseignement des Langues Vivantes", Paris. Mars I936, pp. 97-I05. Artículo del catedrático de la Universidad de Toulouse Mr. H. Gavel, hispanista especializado en el vascuence. Aprueba y complementa mis observaciones de El verso que no cultivó $R$. $D$. Yo comenté a mi turno algunas reflexiones de Mr. Gavel en el artículo de que le envio copia a máquina, por carecer de ejemplares.

Hago votos por su felicidad y me suscribo como su S.

J. Saavedra

No conozco ni tengo esperanza de conocer el attículo del Prof. Cano en la Hispanic Review. 


\section{Santo Domingo 2127 \\ Santiago de Chile, 8. Marzo I939.}

Muy apreciada señorita Clarke:

Su carta del I8 de Diciembre está en mi poder, no así la continuación que en ella me anuncia.

Le envío copia de una modificación que introduje en la hoja 3 de la reseña enviada a la "Revista Hispánica Moderna". No sé empero si haya llegado a ticmpo. Había omitido deliberadamente casi todos los datos que ahí he añadido; pero, puesto que Ud. me dice, y también el Sr. de Onís, que estas cosas interesan allí, tal vez sea mejor no sólo decírselo a Ud. sino en la reseña de su "Bibliografía".

Pero a Ud. debo comunicarle todavía mayores datos:

Pág. 60 de su "Bibliografía". La obra de De la Barra, Del verdadero sistema..., la cita una bibliogr. de este escritor con el título El sistema métrico ritmico de la antigua versificación castellana. Santiago. Imprenta Cervantes. I897. 2I págs. de $177 \mathrm{x}$ ror milímetros.

P. 6r. Los Nuevos estudios. . empezaron a imprimirse en I89r, pero se publicaron en Noviembre de 1892, o en Diciembre. En I891, pero con diferencias, habían aparecido en la "Revista de Instrucción Secundaria y Superior, Tomo II.

En la "Revista de Chile" aparecieron las siguientes publicaciones de De la Barra: 1899, Métrica antigua y rítmica moderna, Sobre los esdrújulos en el verso endecasilabo (Vol. I); Del esdrújulo en el endecasilabo yámbico (Vol. II); Paso del sistema métrico de versificación antigua al rítmico moderno (Vol. III).

No he visto ninguna de las publicaciones mencionadas anteriormente, pero si Ud. lo desea le puedo mandar datos verificados.

P. 62. La ra. ed. de Barros Arana, Elementos... es de I867. Poseo la 6a., Santiago, 1890, en que la Métrica ocupa las pp. 70-127.

P. 85. Poseo una 2a. ed. de la Poética de Martínez de la Rosa, hecha en París, en I834, tomo I. El t. II es de r827 y de la ra. ed.

P. 89. Los tomos de la Antologia... de Menéndez Pelayo son trece, no catorce. Es errata.

El Diccionario de la Rima de 1852 fue editado por: Librería de Rosa, Bouret y Cía. Tiene VI y 386 pp. de I9 x I3 c. Se halla también al fin del Dic. de la lengua cast. en $4^{\circ}$ de la misma Librería. 
Los tomos de las Ideas estéticas con datos sobre retórica y poética en los siglos XVI a XVIII son los II ( 2 vol.) y III ( 2 vol.) de la $I^{z}$ ed. Me parece que II a V de la ed. en 9 tomos. Del siglo XIX no alcanzó a tratar. Estos tomos y la "Bibliografía" de La Ciencia española debería Ud. recorretlos, si no lo ha hecho antes.

Por descuido, no menciono al autor, Amador de los Ríos, de la Historia crítica... en la hoja adjunta a esta carta.

Los tratados escolares a que me refiero son:

I. Manual de Literatura por don Antonio Gil y Zárate. 3a. ed. Valparaíso. 1862. De versificación se ocupa en las pp. 27-45. La $I^{3}$ ed., española, debe de ser de diez años antes por lo menos. La $12^{3}$ la hizo Garnier en París, sin fecha.

2. Elementos de Retórica i Poética, por Raimundo Miguel (sic, sin "de"). Nueva edición completamente reformada en la oratoria sagtada i parte poética, por Un Profesor del Seminario de Santiago. Santiago. I872. pp. 205-256: Cap. XVIII: Del Arte Métrica castellana. La doctrina en esta ed. es la de Bello; pero en la obra española es la de Hermosi1la. Esta se llama Curso Elemental Teórico-Práctico de Retórica y Poética... por D. Raimundo de Miguel, Catedrático en el Instituto de San Isidro, de Madrid. ro: ed. Madrid, Sáenz de Jubera. I922. En las pp. 168-185: Apéndice I. Compendio del Arte Métrica Castellana. A juzgar por el prefacio, la primera ed. ha de ser anterior a I860.

3. Elementos de Literatura Preceptiva por G. René Moreno. Santiago de Chile. I89r. pp. 473-493, versificación.

4. Elementos de Retórica y Poética... por el presbítero Rodolfo Vergara Antúnez. Santiago. I908. Pp. 93-I36: Cap. III: Del arte métrica o versificación $2^{\text {a }}$ ed. corregida: I9r4.

5. Nociones de Literatura por Ignacio A. Pane. Primera parte. Asunción, 1909. Segunda parte. Asunción, 1910. La obra es la tirada aparte de una revista (como su "Bibliografía") y tiene varias numeraciones, en cada uno de los dos folletos que la componen. La versificación ocupa 33 pp. del primero.

6. Lecciones de Literatura Preceptiva... por el P. Ismael Guzmán Ovalle, de la Compañía de Jesús. Santiago de Chile. I9r7. pp. 3ro-398 corre un capítulo sobre versificación.

7. Curso de Literatura (Retórica y Poética). Colección $\mathrm{H}$ (ermanos de las) E(scuelas) C(ristianas). Santiago de Chile. I9r7. pp. 327-389: Cap. III: Versificación o Métrica.

8. Lecciones de Literatura Escolar... por Juan C. Zorrilla de San Mar- 
tín, S. J. $4^{3}$ ed. Santiago de Chile. I929. $5^{a}$ ed. I93I. No sé cuándo apareció la $I^{\text {* }}$

9. Técnica Literarida por E. Solar Correa. Santiago de Chile. I933. pp. I03-r42: Métrica. El mismo autor, en colaboración con E. Tizzoni Lucciano, había impreso en r923 un libro: Idioma Patrio, con Flementos de Métrica en las pp. 38-5I.

Tal vez le he dado más datos de los que Ud. desea. Estos textos escolares no plantean ninguna cuestión nueva. Pero como Ud. ha acogido otros de la misma especie en su "Bibliografia" he pensado que tal vez apreciará estos datos.

No tengo la menor idea de si El Cerrito queda cerca o lejos de alguna gran ciudad. $Y$, en caso afirmativo, si en esa rudad hay oportunidades de adquitir, por cambio o por compra, libros de ocasión, como la Gramática de Nebrija o alguna otra obra por el estilo. Aquí hay algunas que yo cambiaría por otras.

Hago votos por su felicidad y acepte los saludos de su respetuoso servidor.

J. Saavedra

Prof. Tulio Saavedra $M$.

Santo Domingo $2 \times 27$

Santiago de Chile,

24. Mayo I939.

Muy apreciada Señorita Clarke:

Le expreso mi agradecimiento por su carta del I7 de Abril y por el mucho trabajo que se ha tomado para enviarme copia de tantas cosas.

Encuentro poco generoso el artículo del St. ... Casi no contiene más que reservas: lo que sobra y lo que falta. $Y$ esto dicho de modo que enaltece más al articulista que al autor, sin servir bastante al público. Pero es corriente que los "reseñistas" de libros hablen de defectos sin precisar, lo que produce la impresión de que saben más que el autor. Puro impresionismo! No hay obra sin defectos. Por eso, se puede censurar a Homero sin ser capaz de hacer uno solo de sus versos, como dijo el latino. 
No creo que sobren todas las obras que señala el Sr. ... Las materias que deben figurar en un tratado de versificación no han sido fijadas por ningún concilio. Benot empieza por un tratado de acústica y sigue con otro de prosodia, y, para colmo, en forma epistolar. Bello empieza por uno de ortología o, como diríamos ahora, de fonética. $\mathrm{Y}$, en efecto, las nociones fundamentales de la métrica hunden sus raices en la fonética, la acústica, la psicología; y nadic puede extrañarse de que un tratadista quiera dar amplitud a esas bases; aun cuando un lector tenga derecho a aburrirse.

Prosodid, en sentido clásico, es la recta acentuación de las palabras; pero ha sido usada esa voz muchas veces en el de recta pronunciación o silabación; y aun en el de versificación, como es común en inglés.

La tacha que me parece justa y útil es la de reclamar una nota en cada caso, que dijese en qué materias se ocupa cada libro o artículo; pero esto es tarea para toda una vida; y se lograría mejor por colaboración entre varias personas: de las cuales podría ser una el Sr. ...

Sus noticias de libros italianos me serán muy provechosas. La biblioteca de la Universidad de California ha de ser muy rica cuando tiene todo eso y más. No tengo ni conozco el libro de F. Flamini (Notizia stórica, etc.).

Veo que Ud. ha elegido sus noticias con cierto plan, en el que ha tenido papel mi folleto sobre los "Hexámetros". Mucho me interesan, en efecto, los diversos esfuerzos, en varias lenguas, para adaptar los metros antiguos a las versificaciones modernas. Pero me interesan más los fundamentos fonéticos, acústicos, psicológicos (de que hablé más atrás) de la versificación de cada lengua y cada época. Por csto, de los cinco folletos que me mandó el Prof. Morley, me ha sido particularmente grata la lectura de Recent Theories about the Meter of the "Cid". Aun cuando las "Conclusiones" del Prof. Morley son muy sabias y sensatas, procuraré ver el estudio del Prof. Leonard, el único que me atrae entre los tres allí considerados. Cae esta materia de lleno en uno de los temas en que estoy discurriendo yo mismo: la versificación castellana del siglo $\mathrm{xv}$, acerca de la cual he ofrecido un artículo al Sr. de Onís, para la "Revista Hispánica Moderna".

¿Conoce Ud. alguna bibliografía de libros sobre la versificación inglesa, con análisis de las materias que los libros estudian? (Tal como la que reclama el Sr. ...).

Me sería muy provechosa, si existiese, pues busco para el inglés lo mismo que para el italiano. 
Conozco y tengo los tratados de J. B. Mayor (Handbook), J. Schipper (History, el manual), G. Saintsbury (Historical Manual), T. S. Omond (Metrists), y P. F. Baum (Principles). Este último está particularmente bien hecho en la parte inicial y "fundamental" a que me refiero. Pero habrá tal vez otros que vale la pena conocer.

Le envío el pliego dominical de un diario de esta ciudad en que apareció un artículo que escribi hace poco, lleno de erratas y de borrones, y que no vale nada, pero en el que Ud. podrá encontrar algún dato que le interese. A propósito, "Quintín" no es apellido sino nombre de bautismo, lo mismo en el metricista Vila que en el boxeador Romero; por consiguiente, Vila debe figurar en la $V$ de su "Bibliografia".

Gracias nuevamente por sus noticias y también por su of recimiento de ayuda que aprecio altamente. Espero que llegará un día en que reclamaré su palabra. El inglés tiene para mí, sobre todo en la versificación, secretos que vislumbro a penas, y tendrá otros que ni siquiera sospecho. Entonces su ayuda será preciosa.

Yo trato de escribir un tratado de métrica, o mejor de las bases de la métrica, comparativo e histórico. Tengo la síntesis en mi cabeza. Tengo muchos bosquejos, muchísimas notas, secciones escritas; pero no logro darle al todo la forma clara, armónica, plena, aplastante de convicción que quiero que tenga. Es posible que no lo consiga nunca. Pero trabajo y no desespero todavía.

Le deseo a Ud. muchas felicidades y me gustatía saber también si puedo serle útil en algo. Entre tanto, acepte los saludos de su afmo. S.

J. Saavedra

\author{
4 \\ Julio Saavedra Molina, \\ Santo Domingo 2127 \\ Santiago, 26 Diciembre I939.
}

Muy apreciada señorita Clarke:

Recibí hace ya bastante tiempo su carta, tan llena de útiles noticias, del II de Septiembre, y asimismo el folleto Agudos and esdrújulos..., que, como hecho por Ud., es una mina de datos preciosos sobre el tema. 
Por ello y por estas Pascuas mi tarjeta le lleva mis felicitaciones y agradecimientos.

Encargué a mi libreto y recibí los trataditos de métrica de Guarnerio y Flamini. Los otros están agotados por el momento; pero van a buscármelos de ocasión.

Estoy tan fatigado con el trabajo del año (El año escolar termina aquí con nuestro verano, que cae en Diciembre: Pascuas de sol en vez de nieve) que no escribiré hasta en dos o tres meses más al Prof. Leonard, y quizá también al Prof. Caldwell, a quien, en todo caso, presente Ud. mis respetos y mi agradecimiento por su espléndida voluntad.

El Prof. de Onís nada me ha respondido sobre la posibilidad de publicar un artículo tocante a los versos usados en el siglo xv. Mis notas se refieren a la técnica de los ritmos, no a las estrofas. Pero el periodo es "fascinador", como Ud. dice, en todos sus aspectos.

Creo que, al fin, podré el año que viene reanudar mis trabajos sobre métrica castellana, interrumpidos desde 1937 por la preparación de la edición crítica de ciettas obras de Rubén Darío que me encargó la Universidad de Chile, y que ya toca a su término.

Creo que comenzaré por publicar un tratado elemental de métrica, lo más sencillo que pueda hacerlo, sin omitir las cuestiones fundamentales. Así podré dar una idea del conjunto, aunque nunca termine, después, un tratado más completo; y podré publicar las partes que vaya completando, como ser: estudios parciales de cada metro importante. Proyectos!

Mil gracias, nuevamente, y quiera Dios darle fuerzas y felicidad para que prosiga sus valiosas publicaciones.

La Rev. Hisp. Mod. no ha publicado todavía la reseña que escribí sobre su Bibliognafic.

Acepte los saludos de su afmo. S.

J. Saavedra 
Prof. Julio Saavedra Molina

Santo Domingo 2127

Santiago de Chile

2 Julio 1940

Muy apreciada señorita Clarke:

Le debo una respuesta, o mejor, una continuación a su estimada carta del II de Septiembre; y también una explicación por mi retardo. Estuve a fines del año pasado algo enfermo y en seguida largo tiempo fuera de casa. De regreso, ya muy atrasado en mis compromisos de trabajo, he debido dedicar todo mi tiempo a ponerme al día; y ahora llega, con alegría para mí, el momento de continuar nuestras charlas epistolares. Si bien se mira, es aterradora la rapidez con que pasa el tiempo y la lentitud con que uno logra despachar sus pequeños trabajos.

Mil gracias por todas sus bondades y noticias. Voy a escribir al Prof. Leonard en el sentido que usted me aconseja. Al Prof. Caldwell no pienso molestarlo todavía; pero tendré presente su buena voluntad para consultarlo más adelante. Entre tanto, sírvase expresarle mi reconocimiento por su bondad, y decirme si le puedo escribir en castellano, dado que el inglés lo leo pero no lo redacto con corrección.

No sé qué pasa en la dirección de la Revista Hispánica Modema con mis colaboraciones. Prometen publicar pero no aparecen mis envíos. Tampoco quiero preguntarlo, puesto que nació de la revista la invitación a que yo les enviara colaboraciones.

Como usted lo supone, el estudio que he hecho de la versificación del siglo $\mathrm{XV}^{r}$ se refiere a la estructura del verso más bien que a la de las estrofas; y también estoy contentísimo de que usted haya estudiado las estrofas. Pero tampoco he visto aparecer su trabajo. Ahora, casi me alegto de conocer su investigación antes de hacer aparecer la mía: así podré publicarla más completa.

Al fin, he terminado mi parte de colaboración en las Obras escogidas de Rubén Dario publicadas en Cbile que me había pedido la Universidad. El tomo I apareció a fines del año pasado, más exactamente en Noviembre. El tomo II está en prensa, pero creo que no lograremos sacarlo antes de fines de este año. Ha sido un trabajo ímprobo para mí.

$Y$ ahora me voy a poner a trabajar en mi manual de versificación $y$ en algunas monografías anexas. 
Recibí su copia del artículo Agudos and Esdruijulos, y lo leí con mucho provecho. Las obras que usted menciona, o las ediciones son un complemento utilísimo. De algunas nada sabía yo. Por ejemplo: reimpresión de r894 de la Filosofía antigua poética del Pinciano, obra que no he logrado ver hasta hoy, pues no hay ejemplar en Chile, que yo sepa. La mención de su Bibliogr. me había escapado inadvertida.

Su of recimiento de ayuda es por lo tanto, precioso para mí, y lo acepto cordialmente agradecido. La rica biblioteca de que usted dispone y su experiencia en investigaciones sobre versificación serán, así, una contribución inapreciable para mí, y que me dan ánimo para proseguir mis trabajos, ahora que empiezo a tener algo de tiempo que dedicarles. Colega.

Formulo votos por su felicidad y la saludo como su afmo. S. y

J. Saavedra

6

Julio Saavedra Molina

Santo Domingo 2127

Teléfono 6I433

Santiago

8 agosto $194^{\circ}$

Muy apreciada señorita Clarke:

El 2 de Julio tuve el gusto de escribirle, y parece que ese mismo día me enviaba, usted el ejemplar de su reciente publicación: "The Copla de Arte Mayor", que acabo de recibir. Mil gracias por su obsequio y por el placer y provecho que he sacado con la lectura. Hay siempre tanta información en sus opúsculos que es imposible que uno no encuentre cosas nuevas, aun siendo un especialista.

Hay puntos de doctrina en los cuales no estoy enteramente de acuerdo con usted, ni con el Professor Morley en las líneas que usted aprueba de una obra que no conocia y de la cual la primera noticia que tengo es la suya. Pero, no sólo sería largo el tema para ser expuesto aquí, sino que prefiero estudiarlo otra vez y rumiarlo, pues siempre acepto ser yo el equivocado. 
En la p. 204, el verso

Al grande padre Santo e los cardenales

¿no tiene una errata en "grande"? Me parece que el poeta ha debido de escribir "grand".

En la misma página, las "serranillas" en que usted piensa son tal vez las que empiezan:

$$
\begin{aligned}
& \text { Después que nací... } \\
& \text { Moza tan fermosa... } \\
& \text { Mozuela de Bores... }
\end{aligned}
$$

de Santillana; pero ¿cuál es el poema del "Cancionero de Baena", II, Ior y s.? No hay en nuestras Bibliotecas ningún ejemplar del Baena, y me gustaría saber cuál es el primer verso, para buscarlo en otras publicaciones.

Acepte mis felicitaciones por su publicación; son once páginas nutridas de erudición y buen juicio, y que ahora añado a las de los profesores Hanssen, Foulché-Delbosc, y Morley, tocantes al mismo tema.

Soy su afmo. S. y colega.

J. Saavedra

Julio Saavedra Molina

Santo Domingo 2127

Teléfono $6 \mathbf{r} 433$

Santiago

29 Oct. I940

Muy apreciada señorita Clarke:

He leído con placer su bondadosa carta del 19 de Septiembre y no sé cómo decirle mi mucho agradecimiento por la copia de poesías que usted hizo (jcuánto trabajo!) para mí y por mí.

Mi salud, mejor; pero mis años: 60, de los cuales 40 por lo menos de intensa labor en el profesorado y entre libros, con la merecida altísima presión arterial, me obligan a ser circunspecto. 
Y ya que de mí empecé a hablar, seguiré. He terminado, salvo retoques, un estudio que me tenía atorado desde hace años: sobre el octosílabo, verso jamás estudiado, no obstante ser el más antiguo (el uso del alejandrino sufrió interrupciones) y el más popular. $Y$ como es imposible hablar de un metro sin hacer alusión, por lo menos, a teorías generales; en este estudio van en bosquejo puntos de vista generales para toda la versificación castellana. Me faltan, sin embargo, en la parte de "métrica comparada" buenos ejemplos ingleses y de otras lenguas con qué justificar ciertos puntos de vista. $Y$ la terminología inglesa es tan diferente que todo resulta difícil de decir; diferente sobre todo porque el ángulo de visión es también otro, y quizá también otro el ángulo de la sensibilidad auditiva.

Octosílabos como los castellanos no existen, me parece, claramente en inglés. Todo el Song of Hiowatba está ciertamente en octosílabos, pero de un solo tipo: el Four-foot Trocbaic. ¿Podría Ud. señalar algún verso en que hubiera substitución de un troqueo por otro pie?

¿Conoce Ud. algún poema inglés (no digo versos sueltos) Three. foot Dactylic?

Ud. conoce el Handbook de Mayor. En la p. 40 cita una estrofa de Swinburne cuya escansión (no segura) sería de cuatro pies trocaicos con substituciones dactílicas:

\author{
Dawn is \\ dim on the \\ dark soft \\ water; soft and \\ passionate, \\ dark and \\ sweet, Love's own \\ self was the \\ deep sea's \\ daughter, Fair and \\ flawless from \\ head to \\ feet
}

Conoce Ud. algo mejor? ¿Un poema entero?

Me parece que éste podría ser, pero dudo de mi competencia para juzgar, el de Shelley titulado Lines written among the Euganean Hills, October, 1818, y que empieza: Many a green isle needs must be. . .

Recibí una carta del profesor don F. de Onís, director de la Rev. Hisp. Mod. Estuvo muy enfermo y fue operado. Me dice que mi reseña 
sobre su Bibliograpby se publicará pronto. $Y$ que mi artículo (abreviado) sobre la versificación del siglo $\mathrm{XV}$ no calza en el plan de la revista que él dirige, pero sí en el de la de Buenos Aires, dirigıda por A. Alonso, que lo publicará si lo pido.

Recibí también el folleto en inglés del Prof. Leonard, con una gentil carta.

He notado que Ud. en sus trabajos siempre cita la Ortologia y Métrica de Bello según una edición española. Ha de ser buena. Pero la mejor, la que sirvió de base para la muy buena de las Obras completas, no obstante sus muchas erratas (corregidas, por lo demás), es la de I859, hecha en Santiago por su autor, la tercera y última mientras vivió. Tengo un ejemplar de esta obra rara y se lo envío en obsequio por su gentileza, y como un recuerdo de nuestra común afición a las cosas métricas. Va certificado y le añado una bibliografía de De la Barra. De éste hay obras métricas que tengo repetidas. ¿Cuáles le faltan? Las hay también rarísimas, como ese Endecasilabo dactílico, del cual he logrado al fin poseer un ejemplar.

Su opinión acerca de los políticos de allí ha de ser justa. Aunque desde aquí es imposible saber qué haya de verdad debajo de las palabras que hacen llegar al público, y menos por mí, que vivo en círculos apolíticos, no dudo de su apreciación sobre la "great Pan-American propaganda" porque los "political leaders" son iguales en todas partes y lo han sido en todos los tiempos. Ellos son los causantes o los agentes de todas las divisiones y guerras entre los pueblos y entre los habitantes de un mismo pueblo. Dividir para teinar ha sido la divisa expresa o tácita de todos; dominar y entiquecerse y gozar, el fin. En el caso de la unión de todos los habitantes de este continente como una defensa contra los tiranos de Europa, se trata justamente de un contra-ataque a la propaganda de división activada por alemanes e italianos. Esto, aquí en América del Sur ha sido evidente. Le envio un recorte de un diario de ayer no más. Es uno de los mil casos registrados ya en Argentina, ya en Uruguay, ya en los demás países sudamericanos. Y ello es muy claro. Si los totalitarios logran establecerse en cualquier rincón de América, costará un mundo desalojarlos; y toda división, lucha política ardiente, o guerra local, será una oportunidad para ellos.

Allí deben considerar, además, que la América del Sur está casi desierta; la población es muy rala; Chile es tal vez el país más denso en población y sólo tiene cinco millones de habitantes; menos que una gran ciudad de Estados Unidos. Nuestro poder, económico y de toda suerte, guarda relaçión con nuestra poca poblaciợn, 
La unión de todos es la salvaguardia. Y al fin de cuentas, aquí donde; por ejemplo, usted desciende de ingleses y yo de puros españoles, pero esto no es un motivo para que nos consideremos superiores a nadie, ni con derechos divinos sobre nadie, no hay motivos para que nos hagamos guerra, y sí para que nos consideremos partes de un mismo todo, con tierras en exceso y trabajo en abundancia, y la voz de orden debe ser ayudarnos los unos a los otros, considerarnos cristianamente hermanos, intercambiar nuestros productos, nuestros pensamientos, y hasta nuestros afectos.

Pronto, espero volver a poner mano en mi Manual, arrumbado desde hace tres años por los encargos tocantes a $R$. Darío. Trataré también de rehacer mi estudio sobre el "arte mayor" siguiendo otro plan, más completo. Pero me gustaría también serle útil a usted en sus trabajos. Cuando publique (y no sé cuándo) el estudio del octosílabo, creo que habrá más campo para nuevos trabajos: tanto en método como en materias. Es un estudio de larga y paciente investigación.

Deseo que usted goce de perfecta felicidad y acepte los saludos de su afmo. S. y colega

J. Saavedra

En la Bibliografía de De la Barra llevan una cruz roja las obras que tengo duplicadas.

Julio Saavedra Molina

Santo Domingo 21 27

Teléfono 6I433

Santiago

Santiago, Chile, ro Abril I94r.

Muy distinguida señorita Clarke:

Recibí su carta del 2I de Enero hace ya más de un mes y he estado esperando, para contestarle, la posible continuación con noticias del Prafesor Caldwell. Interpreto la no recepción de datos en el sentido de que él no ha podido dedicar atención a mi consulta. Y como por mi parte me he allanado a dejar mi estudio del Ostosilabo sin los datos que 
yo pedía, le ruego no insistir en solicitar respuesta a mi consulta del 29 de Octubre.

Le envío un paquete con tres publicaciones de E. de la Barra. Excuse Ud. que vayan sin empastar y hasta algo desencuadernados. Son libros ya antiguos y que es difícil obtener en perfecto estado. Para adquirir algunas de las publicaciones, ya muy raras, he tenido que comprar a veces volúmenes que contenían vatios folletos empastados en un solo tomo por algún curioso, y han ido quedando repetidos en mi biblioteca (tengo unos 5 mil volúmenes) los tres que le mando, entre otros sobre otras materias. Si más adelante logro obtener los Estudios de I889 o algún otro folleto importante (históricamente importante, porque el valor actual de estas publicaciones no es mucho), se lo remitiré también.

Me alegraría saber, además, si Ud. tiene nterés especial en poseer alguna publicación chilena. Quizá pudiera yo procurársela. Somos tan pocos en el mundo los que nos interesamos en cuestiones, de métrica que debemos auxiliarnos en la medida de nuestras fuerzas.

Para responder a su pregunta "Does your work include the origin of the line or just the study of the verse as it appears in Spanish?" me parece lo más adecuado describirle en pocas palabras mi trabajo. Consta de nueve capítulos de muy diverso largo, cuyos títulos algo dicen del contenido, y por esto los voy a copiar aquí: I, Ojecalla bistórica (tanto del uso de los versos mismos cuanto de las teorías explicativas); $I I, \mathrm{Va}$ riedades acentuales del octosilabo (catálogo, clasificación y estadística de todas las formas que he hallado); III, Acentos predominantes $y$ traslado de acentos secundarios (ordenación de tipos acentuales); $I V$, Acentos secundarios y tipos ritmicos que contribuyen a formar; $V$, Acen tos extraordinarios (versos de acentuación excepcional); VI, Las pausas y su influjo en los ritmos; VII, Pies métricos; VIII, El octosílabo rítmico (o acentual, para el que solicité a Ud. algunos datos en octubre); IX, Apéndice (con poemas analizados para ejemplo).

En el Cap. I, que es el que más relación tiene con su pregunta, tomo el octosílabo tal como aparece en el siglo xIv, y apenas aludo a los versos que desde el Cid (hemistiquio) podrían recordarse. Mucho menos a los modelos latinos que citan Bello, Milá, Menéndez Pelayo y otros.

No examino ni las estrofas en octosílabos ni los géneros poéticos o composiciones que lo han preferido. He querido solamente poner en claro cuál es su estructura rítmica y el lugar que ocupa en la versificación.

Mi ẹstudio del Arte mayor es paralelo al del Octosilabo, pero sólo 
tiene cinco capítulos. Creo que los publicaré este año en Santiago, seguidos de una Teoria de la versificación basada en un examen del octosílabo y del verso de arte mayor. Estos tres estudios se completan mutuamente; los dos primeros están terminados y el tercero, que dará el nombre al libro, lo estará pronto, si Dios quiere.

Mil gracias por sus buenos deseos tocantes a mi salud, que hace meses ya ha mejorado mucho. A mi turno, hago votos porque Ud. conserve, no digo su salud, que en una joven, como a Ud. la supongo, ha de ser espléndida; sino su entusiasmo por las cosas métricas y su gracia femenina, que advierto a través de sus finezas. $Y$ acepte los saludos de su afmo. colega en aficiones.

J. Saavedra

9

Julio Saavedra Molina

Santiago, $\mathrm{r}_{7}$ abril $\mathrm{r} 94 \mathrm{I}$.

Muy distinguida señorita Clarke:

Le escribí a Ud. hace una semana diciéndole que no había recibido yo su carta anunciada. Acabo de recibirla y me apresuro a anunciárselo.

También leo yo con mucho agrado sus cartas y las espero como Ud. Señal de que nuestra correspondencia no se va a interrumpir pronto.

Mucho tengo que contestar a su carta del 20 de Marzo; pero, a fin de lograr el correo de hoy, tendré que contentarme en ésta con lo más importante.

Me dice Ud.: "Professor ...stressed the fact that the fundamental difference between English and Spanish verse scansion makes comparison of verses almost valueless and so all examples must be used with caution". Agradezco el consejo por lo que tiene de benevolencia; pero le voy a decir brevemente por qué pienso que Mr. .... está equivocado: jno hay tal diferencia fundamental en la escansión! $\mathrm{Ni}$ en la escansión ñi en nada, mi apreciada Sta. Clarke. Tal creencia es un prejuicio y un error. $Y$ sería una gran calamidad que podría ocurrirle a Ud.: joven, entusiasta y llamada a ilustrar la métrica de entrambas lenguas, la castellana y la inglesa, que Ud. empezase por acoger ese error. Yo perdí varios años de mis estudios antes de adquirir la convicción de que la Métrica es una, así se trate del çastellano, francés, inglés, o alemán, o del 
araucano, el árabe, o el griego antiguo. El prejuicio me vino al leer las explicaciones de los metricistas ingleses, tan enrevesadas, ilógicas y orguIlosas; y al compararlas con las de los metricistas castellanos o franceses, tan superficiales, estrechas e incompletas. Me refiero, claro está, a los autores que entonces conocía, los más corrientes y elementales. Cuando empecé a ver claro ya estaba fatigado, y he tenido que rehacer mis primeros trabajos. Ud. comprenderá mejor lo que estoy diciendo, y quizá me dará razón, cuando publique los trabajos de que le hablé en mi carta del ro. He llegado a elaborar una teoría de conjunto tras largos años de investigación con rigoroso método inductivo, y ahora compruebo cada día la verdad de lo que he logrado ver aplicándola a nuevos casos.

Si Ud. admitiese un consejo de mi parte, dictado por mi antigüedad en el oficio métrico y por mi aprecio hacia la obra venidera de Ud., le daría éste: dedíquese a estudiar la métrica comparada del castellano, en que tanta competencia ha adquirido, con la del inglés, lengua en que tiene sobre mí la ventaja de hablarla como materna. Si así ocurriese, más adelante le podría comunicar experiencias mías que a Ud. le acortasen el camino; y hasta quizá podríamos colaborar en algún estudio.

Yo vacilo en ciertos detalles de pronunciación y uso que no se aprenden sino en el ambiente materno. Cuando le pregunté en Octubre si el poema de Shelley podría tenerse por compuesto en el metro del octosilabo castellano, pero con substituciones de pies, tal como la estrofa de Swinburne, que, sin embargo, tiene otro movimiento rítmico, fue porque mi lectura (de extranjero) me of rece dudas en el silabeo. Y, para saber cuál es el metro de un poema, lo primero es silabear bien; lo segundo, acentuar bien; lo tercero, espaciar bien; ya que los ritmos varían según el uso que se haga de esos elementos: sílabas, acentos títmicos y pausas rítmicas. Cuando Ud, ha hecho eso y bien el verso está escandido. ¿Cómo lee Ud. el verso Many a green isle needs must be y los siguientes de Lines written among the E. H.? ¿Dice Ud. las palabras Many a haciendo 2 ó 3 sílabas? Si las une, el verso tiene 7 sílabas y equivale a un octosílabo castellano. Si las separa, el verso tiene 8 sílabas y es un octosílabo inglés (eneasílabo en castellano). Pero hay que ver cuál es la medida pređominante en el poema, que es largo, pues ese primer verso puede ser una excepción. Lo leo (extranjero!) uniendo, y ese verso lo descompongo en 4 troqueos: Mány a / gréen isle / needs / must / be */. El verso es cataléctico en una sílaba que represento por *.

Pero, por favor, no consulte a nadie; me interesa su lectura espontánea y sin un posible cambio por influjo de ideas ajenas.

Las respuestas del Profesor ... están dadas bajo el influjo de un 
equívoco. Ël atribuyó a "octosílabos" el sentido que para él tiene "Octosyllabics". Por eso menciona el Lay of the Last Minstrel de Scott y Christabel de Coleridge, que, en efecto, están compuestos en metro "Fourfoot iambic" o "Four-stress", equivalente al "octosyllabe" del francés y al eneasílabo nuestro, porque nosotros y los italianos contamos una sílaba teórica después del último acento, para la terminología.

Pero nuestro "octosilabo" es equivalente al "Four-foot trochaic" o Four-stress trochaic", una de cuyas formas, la que Ud. me señala justamente en el poema de Juan de Mena (Cancionero de F, -D, t. I, p. 206-208, que, a propósito, tengo y ha sido mi principal fuente para el estudio del arte mayor), es la que usa Longfellow en Hiawatba, me parece que sin excepción, y por esto le preguntaba si Ud. le había hallado alguna excepción, es decir, alguno de los cuatro troqueos de cada verso reemplazado por algún yambo o por otro pie (anapesto, dáctilo, por ej.). "Pie" en mi carta significa lo que Bello llama "cláusula rítmica", y que los antiguos llamaron asi, pero que Encina y otros echaron a perder por ambigüedad cuando empezaron a llamar pie al verso o al quebrado del verso.

El hemistiquio o el quebrado de los versos de Poe's Raven es también un equivalente del octosílabo castellano, como lo son los de Locksley Hall de Tennyson (Vea Ud. la p. 88 de mi folleto sobre los Hexámetros).

Pero el metro de Hidwatha, The Raven, Locksley Hall (prescindiendo en éstos de que la circunstancia del renglón largo o doble no es despreciable) por un lado, y el metro del Lay o de Cbristabel, por otro lado, no son el mismo: el primero es trocaico, $\mathrm{ax}$ ax ax ax, descendente; el otro es yámbico, $\mathrm{xa} \mathrm{xa} \mathrm{xa} \mathrm{xa}$, ascendente. La diferencia entre el metro del Lay (primera parte) y el de Christabel consiste en que Scott admite y pocas veces la substitución de algún yambo por un troqueo y Coleridge admite eso y también la substitución de yambos por anapestos. De donde resulta que el verso de Scott es "octosyllabic", pero no el de Coleridge, que a menudo tiene diez o nueve sílabas, y no sé si más. Pero no se aparta del ritmo de 4 acentos, Four-beat. En otros términos, Scott en muchas secciones de varios de sus poemas versifica "silábicamente", como es corriente en castellano; y Coleridge versifica "rítmicamente" o "acentualmente", como es corriente entre alemancs.

La hora apremia y corto aquí mi respuesta.

He señalado en la hoja de su traducción con lápiz rojo algunos puntos en que no supe explicarle con claridad en mi carta de Octubre lo que quería, puesto que Ud. no me comprendió bien. Excúseme y lę ruego devolverme la hoja porque me interesa çonservarlas. 
Acepte, apreciada Miss Clarke, los saludos de su afmo. S. y amigo. J. Saavedra

Mil gracias por su of recimiento de copias de poemas ingleses. Tengo ediciones de casi todos los mejores poetas ingleses y norteamericanos; pero de Swinburne sólo unas poesías escogidas, entre las cuales no se halla la de donde Mayor extrajo la estrofa en cuestión, y que él tampoco menciona.

IO

\author{
Julio Saavedra Molina \\ Casilla I4I9 \\ Teléfono $6 \mathrm{~T}_{433}$ \\ Santiago \\ 9 Julio I94I.
}

Muy apreciada Señorita Clarke:

Sea lo primeto expresarle mi gratitud por su carta tan gentil, y con tantas valiosas copias y notas, y por el libro de poemas de Swinburne, que ha venido a sacarme de la ignorancia en que estaba del nombre y demás cualidades del original citado por Mayor.

Ayudado por sus notas sobre silabeo y acentuación, he confirmado mi creencia de que los poemas en cuestión de Shelley, Longfellow, y Swinburne están compuestos en octosílabos, es decir: en el ritmo y metro a que pertenece el octosílabo castellano; pero con las diferencias propias del uso o usos preferidos en inglés y en castellano. Y Ud. misma lo advirtió ya, puesto que en su carta me dice que a Ud, le dan también la impresión de octosílabos.

Uno de los ritmos que sigue el octosílabo castellano es el de cuatro troqueos (ax ax ax ax, tánta tánta tánta tánta). Y éste es también el que siguen los poemas a que me refiero, en inglés. Pero, de acuerdo con la técnica inglesa y alemana, de reemplazar uno u otro de los troqueos, y preferiblemente los primeros, por otros pies, y a menudo por dáctilos (axx, tántata), la fórmula $\mathrm{ax}$ ax ax ax es alterada a veces, y cambiada por axx ax ax ax, 0 bien ax axx ax ax, o bien ax ax axx ax; y también truncada al fin (Shelley), o truncada verso por medio (Swinburne). Shelley, además, introduce sílabas en anacrusis, to que equivale a reemplazar el primer troqueo por un anfíbraco xax o por un peón tercero xxax. Todo lo cual es perfectamente antiguo, pues los griegos ya lo hacían en su versificación çuantitativa, 
$Y$ son muchos los ritmos usuales del castellano que tienen con los de otras lenguas, y con algunos del inglés, la misma relación. El arte mayor, por ejemplo, tiene su equivalente en inglés: yo cito Glenara de Campbell en mi estudio respectivo. Por momentánea confusión, había nombrado aqui The Turkish Lady, que cito en mi estudio del octosílabo. Campbell tiene dos o tres poemas más que a mí me suenan como ritmados así.

$Y$ este es uno de los trabajos en que estoy yo empeñado: señalar los puntos de contacto de las diversas métricas, particularmente del castellano con las otras que conozco un poco: portugués, italiano, francés, inglés, alemán, ... Del estudio comparativo tiene que resultar la comprensión mutua, que hoy no existe, porque se carece de puntos de contacto y referencia. Ni ha existido nunca: basta hojear los tratados de métrica de cada una de las lenguas mencionadas para advertir la incomprensión de las bases generales de la métrica. Generalmente no están de acuerdo ni se entienden siquiera los metricistas de una misma lengua entre sí. Compare Ud. las doctrinas de Hermosilla, de Bello, de Coll y Vehí, de Benot, de Jaimes Freyre, etc. en castellano: son todas distintas. Compare las de Mayor, Saintsbury, Rudmose-Brown, Baum, etc. en inglés: todas difieren en cosas fundamentales. Hay, por lo mismo, un gran trabajo que hacer de conciliación, y de penetración; porque los puntos de contacto corren profundamente, como esas raíces que se comunican subterráneamente y alimentan diversas plantas.

Si Ud., que conoce y lee varias lenguas, investigara en el mismo sentido, convencida, como lo estoy yo, de la unidad de la métrica, podría cosechar valiosísimos frutos. Pero hay que comenzar por abandonar todo criterio de autoridad. No importa lo que hayan dicho ciertos eminentes sabios, ni lo que piensen ciertos profesores. La verdad está detrás de los hechos, y se entrega a quien la busca con paciencia y buen sentido.

Le decía en una de mis cartas anteriores que tal vez publicaría en Santiago este año mis tres estudios terminados (Octosílabo, Arte. Mayor, Teoria). Pero un suceso imprevisto me obligará a dedicar mucho tiempo a algo enteramente dispar: he vendido la casa en que vivía desde I923 y voy a construir otra. Es la causa porque $U d$. ha de dirigirme su correspondencia hasta nuevo aviso a la dirección Casilla 1419, Santiago, Chile. Cuando tan desagradable periodo haya pasado y recobre mi calma para pensar y hurgar mis libros, que ya están en su mayor parte encajonados y guardados para una noche de seis meses; entonces haré imprimir, si Dios me da vida.

Le prometí, además, en la última, ampliar algunos conceptos de ella; 
y aunque ésta ya va larga y algo he dicho ya de lo que pensaba añadir, le declararé aún que, después de unos doce años que presto especial atención a la métrica, la noción más importante y fecunda que he adquirido es la de que la técnica "silábica" o de sílabas contadas (la más corriente en castellano, francés, italiano, portugués) y la técnica "rítmica" o de acentos contados (la más común en inglés, alemán, y otras lenguas germánicas) no son sino algo como las dos caras de una misma medalla: direcciones distintas en el procedimiento, a partir de unas mismas bases. Las bases son nociones de naturaleza psíquica, comunes a todos los humanos; nociones de ritmo, de interpretación subjetiva de ciertos estímulos físicos, comunes a la danza, la música y la poesía. Esto es lo que trato de explicar, con ejemplos sacados del castellano particularmente, en mi Teoría.

Pues bien, parece que esto mismo ha sido ya abordado y aun explicado, y nada menos que en Estados Unidos. Digo "parece" porque las noticias que tengo provienen de dos libros en que solamente se alude a dichos trabajos. Y el autor de la noticia de segunda mano no ha querido hasta hoy contestarme cartas que le he escrito inquiriendo noticias.

Se trata de dos libros que tal vez estén en la Biblioteca de la Univ. de California: Antología de líricos colombianos, Introducción etc. por Carlos Garcia Prada, Ph. D., Catedratico de Literatura de la Universidad de Wasbington, Seattle, Bogotá, I936, t. I; y González Prada, Antologia poética, Introducción etc. de Carlos García Prada, etc., México, I940. Me mandó ambos libros, a principios de este año, el Sr. García Prada, y después de leer ambas introducciones le pedí mayores datos sobre los autores de estudios métricos que cita, particularmente en las páginas 34 y 38 , algunos de los cuales encontraba mencionados por vez primera. Lea Ud. esas Introducciones; quizá estén también alli los tratados o memorias que interesarán tanto a Ud. como a mí. En la exposición del Profesor García Prada hay un poco de tropicalismo, pero hay cosas valiosas. $Y$ parece que él es también un estudioso de métrica. En carta del I 3 de Febrero decía al Sr. García Prada: "No conozco a varios de los metricistas que Ud. menciona en la p. 34 (del libro de I940). ¿Le sería posible darme algunos datos de la obra a que se refiere Ud. de Milán, Cortejón, Jaime Monell, y Pérez Hervás? Son nombres para mí nuevos. Cortejón ¿es acaso el comentador del Quijote? ¿Dónde y cuándo se publicaron? Y si Ud. quiere añadir algún dato de fondo, tanto mejor. Los estudios experimentales de que habla en la p. $3^{8}$, ¿dónde y cuándo se publicaron? Ignoro todo eso, aun cuando yo, por mi cuenta, he llegado a resultados semejantes". - Los autores que menciona en la 38 son: Burt Minor James, Fred Newton 
Scott, Herbert Woodrow, Louis de Vries, Tomás Navarro Tomás. Este último lo conocemos Ud., que lo cita en su Bibl., y yo.

Mi principal punto de vista es que las nociones básicas de la métrica son de naturaleza subjetiva, personales; y esta es la causa de que cada autor aprecie los mismos hechos físicos de modo diferente. $Y$ como, no dándose cuenta de eso, los autores tratan la materia como si fuese de naturaleza objetiva, idénticamente observable por cada cual, unos acusan a los otros de no entender ni saber nada.

Como Ud. ve, Sta. Clarke, hay mucho que investigar. Y quizá podamos hacer algún trabajo juntos.

Books Abroad y Mr. Mapes me mandaron copias del artículo de Mr. De la Torre. Mil gracias por su noticia.

Si Ud. lee tratados de métrica inglesa, tome grandes precauciones para no recibir sin discusión a fondo lo que enseñan. $Y$ acepte los saludos de su af. S.

J. Saavedra

Esta carta va certificada, como precaución, porque ahora se pierde mucha correspondencia: uno de los daños reflejos de la guerra en el mar.

Prof. J. Saavedra

Casilla I 4 I9

Santiago, Chile, I2 Dic. r94I.

Muy apreciada señorita Clarke:

No he querido dejar pasar esta Pascua sin manifestarle mis deseos de felicidad para usted y su familia. Ahora que América está en guerra, los buenos deseos de amigos y conocidos han de manifestarse. Al mismo tiempo, quiero decirle que estoy alarmado con su largo silencio. Su carta tan gentil del 30 de Mayo, y tan útil para mí, se la contesté yo el 9 de Julio. Después, el 77 de Octubre le envié un folleto: "Sarah Bernhardt y Rubén Darío". Ambos envíos fueron certificados.

¿Tal vez usted me ha escrito y se ha perdido su carta? Mucho le agradecería que me diera noticias de usted.

Soy siempre su muy atto. colega en métrica y su seguro servidor.

J. Saavedra 
Julio Saavedra Molina

Casilla I4I9

Santiago

Chile

30 Junio I942.

Muy apreciada señorita Clarke:

Hace ya mucho tiempo que recibí su carta del Is de Enero y los "Reprinteds from Hispanic Review", aunque ambos envíos me llegaron con algo de atraso. Gracias por su gentileza al acordarse de mí, y por lo mucho que he aprendido al leer ambos artículos, y por el placer que me han dado. Todo ello, empero, ha sido poca cosa al lado de una frase de su carta, que me ha traído, además, preocupado de muy variadas maneras: "your letter of July 9, which, incidentally, arrived almost simultaneously with Ramona, our new baby".

¿De dónde pude yo sacar que usted era una "Miss"? ¿Y cómo pudo usted dejarme continuar en el error mío involuntario? Tiene usted que empezar por perdonarme esta falta y aceptar la misión de excusarme ante su esposo, a quien nunca pude antes desearle la felicidad de que, a pesar de mi omisión, ha de gozar a su lado y en compañía de sus dos criaturas. Presente, además, mis respetos a la Señorita Ramona, que con tan justificado motivo retardó la respuesta de usted a mí. Y, como al fin y al fallo, señorita o señora, para un corresponsal tan lejano y cuasi abuelo como yo, poco quita ni pone, permítame seguir llamándola "Miss" como en el pasado.

De sus dos artículos, mayor satisfacción me ha dado, por referirse a un tema que yo mismo he estado trabajando, The Spanish Octosyllable que Redondilla and Copla de arte menor; sin por esto menospreciar ninguno de los dos. Su "mise au point" de los orígenes probables del octosilabo es irreprochable y completa muy oportunamente y ata sin fallas los cabos sueltos que dejó mi maestro Hanssen. Me ha obligado usted con esto a citar una vez más el nombre de usted en mi estudio del octosilabo.

En la p. 4 copia usted unos renglones de Henríquez Ureña, quien a su vez cita unos versos de Alfonso el Sabio, que el autor de La versificación irregular llama "octosilabos". Son, en verdad, eneasilabos.

Espero ver pronto publicados sus artículos sobre los esdrújulos en la 
época anteclásica y sobre las estrofas, que como siempre, contendrán esos finos detalles que usted observa $\tan$ bien.

No conozco al Profesor Dondo. ¿Es autor de alguna obra sobre versificación francesa?

Mis conocimientos de lenguas extranjeras no son lo que usted se imagina, amplios y profundos. Salvo el francés, y naturalmente el castellano, mis conocimientos son fragmentarios. ¡Hay tantas maneras de conocer las lenguas! Hay personas que hablan una lengua extranjera sin saber nada de gramática, métrica o literatura. Yo no hablo sino el francés con facilidad, pero he estudiado la métrica de varios idiomas. De la comparación he sacado un provecho enorme. Por esto mismo, la colaboración con una persona de otra lengua, como usted, por ejemplo, me sería provechosa.

Su idea de hacer algo tocante a la versificación del "modernismo" me place. Ya tengo adelantado algo en ese camino: el tredecasílabo, el hexámetro, el arte mayor, el eneasílabo. Puntos de vista necesarios, como antecedente, para poder entenderse. Pero de los dos primeros solamente he publicado las páginas que usted conoce; lo demás está inédito y forma parte de mi libro, que por el momento tengo abandonado, pues necesito de mi biblioteca para verificar muchos detalles. Y mi biblioteca sigue guardada, amontonada, en cajones clavados.

La escasez de ciertos materiales de construcción tiene la culpa de que mi casa esté inconclusa todavía. Aquí se produce fierro y cobre, entre otras cosas; pero no se convierte esos minerales en alambres, cerraduras, etc. Tienen que ir a Europa o a Estados Unidos para que de allí vuelvan elaborados. La guerra, con su escasez de fletes marítimos, ha entorpecido todo eso; y la industria chilena no logra todavia hacer todo el trabajo que antes de la guerra encomendaba al extranjero.

Estoy, pues, en cuanto a terminación de mi libro Tieoría de la versificación (basada, como le dije en otra oportunidad, en un estudio del Octosílabo y del Arte mayor, y también en parte, del Eneasílabo, el Endecasilabo, y el Tredecasilabo), en el mismo punto que hace un año. Sólo he logrado adelantarlo haciéndole un índice alfabético de materias. Si logro instalarme pronto en mi nueva casa, es posible que pueda ponerlo en limpio este año. De Buenos Aires me han escrito pidiéndolo para la editorial Losada; pero yo prefiero imprimirlo aquí, bajo mi vigilancia. Ojalá que así sea en 1943 .

Nunca he sentido más profundamente el significado de la frase $\operatorname{Ars}$ longa. Luenga, larga y dura. ¡Cuánto cuesta de paciencia, esfuerzo y fatiga una simple página de observaciones! Me habla usted de mi folleto Rubén Dario y Sarab Bernbardt. Son ¿cuántas páginas? I8? 20? Pues 
bien, tuve que leer meses y meses los diarios de I886 a I889, tomar innúmeras notas, barajar incontables observaciones y meditaciones para llegar a unas cuantas frases de sintesis. Usted, que también es paciente y labora parecidamente, lo sabe bien: Art is long. Preciso es que uno sea verdaderamente maniático para continuar en esta brega. $\mathrm{Y}$ en estos tiempos de brutal materialidad, de matanza y rapiña, mentiras y traiciones.

Confío, sin embargo, en que encontraremos fuerzas morales y materiales para hacer un trabajo sobre el modernismo. ¿Qué campo preferiria usted? Los metros, las estrofas, las composiciones? Su descripción, su historia, su interpretación? La materia es vastísima, si se abarca en todo el período y en todos los países, y desde todos los ángulos. Quizá fuese preferible tomar sólo un grupo de autores, por ejemplo, los llamados precursores del modernismo (Gutiérrez Nájera, Martí, Díaz Mirón, Silva, Rueda, ...) y los modernistas propiamente tales (Dario, Herrera, Lugones, Nervo, Chocano, Valencia, Unamuno, Villaespesa, Valle-Inclán, los dos Machado, Marquina, ...).

Las dificultades de los correos y la censura no son ciertamente para dar alientos; pero...

Gracias por sus buenas palabras tocantes a mi salud. No estoy mal, en efecto. $Y$ aunque lo natural en usted, que es joven, es hallarse en buena salud, le retribuyo sus palabras, deseando para toda su familia un tan gran bien como ese.

Mucho me gustaría conocer por fotografía a la bien venida Ramonita, y a su hermana o hermano mayor, y a su esposo, a fin de corregir mis imágenes, formadas con pura imaginación.

Ojalá que usted me comunique algo de lo que haya avériguado tocante a los libros o autores que cita el profesor González Prada.

Como el año pasado, cuando le escribí mi anterior, aquí es invierno y llueve. Ninguna señal se deja ver aún del retorno de Proserpina. Pero tenemos paz. Y esto no es poco.

Saluda a usted cordialmente su colega en métrica y su $\mathrm{S}$. 


\author{
Julio Saavedra Molina \\ Casilla I4I9 \\ Santiago, Chile, \\ 24 Nov. r943.
}

\title{
Apreciada señorita Clarke:
}

Recibí hace ya mucho tiempo, pero en vísperas de un accidente que he sufrido a la vista, su carta del I 2 de Febrero de este año, que lei con mucho agrado e interés. Formé entonces el propósito de responder puntualmente a sus preguntas; pero, como ya he dicho, mi ojo derecho sufrió un desprendimiento parcial de la retina, y los médicos me prescribieron reposo absoluto de los ojos. Estaba terminando de poner en limpio el estudio del Octosilabo, de que le he hablado otras veces, y tuve que dejar de mano todo trabajo, toda lectura y sobre todo la escritura a máquina, que es lo que me hace peor, según parece. He intentado hacer copiar por otras personas; pero sin resultado satisfactorio: parece que sólo yo puedo tener en cuenta todos los detalles de una buena copia.

Afortunadamente voy mejor; y aunque la prescripción médica de descanso absoluto continúa, me permito de vez en cuando la agradable licencia de escribirle a los amigos. No he querido hoy que pase más tiempo sin dirigirle algunas palabras y sin desearle para dentro de un mes, cuando esta carta llegue a su destino, según supongo, unas felices Pascuas y mejor Año Nuevo en compañía de su esposo e hijos.

Recibí y leí con gran provecho sus dos artículos de la Hispanic Review: The Copla Real y The Fifteenth Century Copla de Pie Quebrado. $\mathrm{Y}$ también proyectaba decirle algo sobre cada uno. Pero así es la vida: rosario de propósitos, buenos y malos, que van quedando a lo largo del camino. "En los zarzales del camino deja alguna cosa cada cual: la oveja su blanca lana, el hombre su virtud". Y sus esperanzas!

Le hice remitir yo también un folleto: El primer libro de R. Dario.

Creo haberle dicho ya que mi obra sobre versificación, o Teoria de la versificación, en cuatro partes, está totalmente terminada, desde hace meses, o mejor años. Ya he logrado poner en limpio la primera: El Octosilabo castellano, y se publicará, Dios mediante, en 1944 en los Anales de la Universidad. El espacio de este año 43 está todo ocupado por cosas del Centenario, y su conmemoración. Seguirán después las otras partes, si logro tener vista para copiar a máquina. 
;Qué lástima que estemos tan distantes en el espacio, usted y yo, y en el tiempo! Sería tan fácil decirle de viva yoz mil cosas que deseo. Pero no hay esperanza de que yo vaya por alli. Y en mi país es tan dificil publicar cosas de nuestra especialidad, sobre todo sin erratas, sin defectos. que desfiguran totalmente lo que uno piensa.

Le ruego darme noticias de usted y de sus lecturas y obras.

$\mathrm{Y}$ reciba un cordial saludo de su $\mathrm{S}$. $\mathrm{y}$ colega.

J. Saavedra

I4

Julio Saavedra Molina

Calle Solar 0385

Santiago, Chile.

I7 Abril 1945.

Muy apreciada Señorita Clarke:

Gracias por su buena carta del I6 de agosto último, que hace ya bastante tiempo que está en mi poder, aunque puso también bastante en viajar hasta aquí. Gracias también por su copia del artículo "The Early Seguidilla", que leí con provecho al recibirlo. Esperando la publicación de dos colaboraciones a la revista Atenea los días han pasado. Pero hoy le despaché al fin un paquete certificado con los dos números en cuestión y le envío mis saludos.

Gracias sobre todo por el recorte en que aparecen retratadas sus dos hijitas y Bobo, el conscripto que usted ha dado a las Américas. Muy lograda la fotografía y muy agraciadas las criaturas. Ramona me recuerda una de mis nietecitas: los niños fácilmente se parecen unos a otros.

Lo que no logro entender es por qué, siendo usted de soltera D. C. Clarke, el artículo la llama Mrs. S. S. Shadi. Su esposo es Mr. Shadi; de acuerdo. ¿Se llama, acaso, Mr. S. S. Shadi, y allí se llaman las esposas con todo el nombre del marido?

Muy interesantes las citas que usted hace de Gonzalo Correas. No las conocía; o si las había leído, no había reparado en los puntos que usted pone de relieve.

Los "Anales" siguen sin publicarse. $\mathrm{Y}$ por consiguiente, mis traba- 
jillos sobre versificación sin salir a luz. "Atenea", de la Universidad de Concepción, ha publicado lo que ya le anuncié, y que usted verá. La "Revista Chilena de Historia y Geografía" está publicando por partes una "Bibliografía de R. Dario", que le enviaré cuando se termine. En Buenos Aires se va a publicar, según parece, un librito en que se recogen algunos de mis ensayos literarios, o críticos; no sé cómo llamarlos mejor.

Un tiempo alimenté el proyecto de escribir una biografía de $\mathrm{R}$. Dario, tal como usted cree que podría componerla; pero mis posibilidades materiales para soñar en muchos trabajos dispares pasaron ya. Me contentaría con ver publicadas mis investigaciones sobre versificación. Le dije ya, me parece, que mi estudio del Octosilabo, que alcancé a poner en limpio, ayudado por una escribiente, lo entregué a la dirección de "Los Anales" para I944. Pero los de I942, segundo semestre, no salen todavía a luz. Calcule usted qué paciencia se necesita. Trabajando un poquito de vez en cuando, he logrado también poner en limpio casi todo El arte mayor, segunda parte de la obra. Ciertamente que no la olvidaré a usted, en cuanto tenga algo impreso.

Celebro que usted haya emprendido la composición de una Historia de la literatura romance. Es un género de investigación más generoso, porque da mayor lugar a la imaginación y hay mayor público que lo acoja.

Saludo a Verna Carol Shadi! Mi segunda nieta: Eugenia, una linda criatura; aunque rubia como Ximena (la mayor) es más hispánica que ésta; nació también (Eugenia) a principios de $x 944$.

Las observaciones del Profesor Morley que usted me comunica son, me parece, muy acertadas, como que vienen de persona tan competente. Pero hay un ángulo de visión en que nunca se colocan los metricistas, trátese de Hanssen, Foulché-Delbosc, Henriquez Ureña, u otros; y es que las "letras" de canciones no se pueden parangonear con los poemas escritos para ser leídos. Ëstos llevan en sí toda su métrica; las "letras" son sirvientes de la música, y es la música la que les da el metro. Lo digo largamente en mi Teoría. La seguidilla era la letra de un canto y baile; estaba sujeta a todos los caprichos de la música; sin la música puesta al lado, no hay nada que decir de definitivo sobre la letra. La seguidilla moderna es una regularización de la letra o las letras antiguas, para decirla sin música. En suma, otra cosa.

Mis ojos no han mejorado; pero me he ido acostumbrando a no temer la amenaza de ceguera. Deseo a usted y a los suyos la mayor felicidad, y acepte mis saludos. 
I5

Julio Saavedra Molina

Solar 0385

Santiago, Chile,

I4 Sept. I945.

Muy apreciada señorita Clarke:

Contesté su buena carta del I 6 de agosto de 1944 el 17 de abril último y en ella le daba también las gracias por su valioso artículo "The Early Seguidilla". Le anunciaba también el envío certificado de un paquete con dos números de la revista "Atenea". El día de la rendición de Alemania le dirigí también una felicitación, y hoy la completo, cuando la paz total ha llegado tan gloriosamente para su patria.

Al fin, puedo enviarle impreso mi estudio de El Octosilabo castellano, que le remito en paquete certificado junto con otro folleto. El arte mayor está también en prensa, y si Dios quiere estará listo antes de fines del año.

Era imposible para mí publicar aquí de una vez toda la obra Teoría de la versificación tal como la compuse y estuvo lista, hasta con un índice alfabético, me parece que en I942. He tenido, pues, que seccionarla; y, lo que fue peor, que anticipar en El Octosilabo, El Arte Mayor, y un tercer artículo que he hecho con otras secciones (Otros tres grandies metros), que anticipar noticias históricas y parte de la teoría. Todo lo cual ha producido un cierto desorden de composición en la obra, que se verá claro cuando termine la publicación de todas las partes. ¿Qué se le va a hacer! Pero, como no se trata de una obra de arte, sino de ciencia, me consuela de este daño artístico la consideración de que aparecerá publicada antes de que yo termine tal vez mi jornada. De otro modo, mi trabajo de varios años se habría perdido. Nadie se interesa por las obras póstumas de otro prójimo.

Hago votos por que la felicidad acompañe a usted y a los suyos; y la saludo cordialmente.

J. Saavedra 


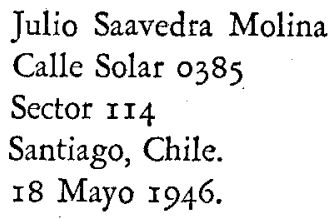

Muy apreciada señorita Clarke:

Contestando mi carta del 24 de noviembre de r943, me escribió usted el 16 de agosto de 1944 ( Por última vez? No he recibido otra misiva suya posteriormente): "I am so eager to see your work on Teoría de la versificación..." Me apresuré, en consecuencia, no bien dispuse de ejemplares de El Octosílabo castellano, a enviarle uno certificado (No. 38806 , del 15 Sept. 1945), como asimismo de El verso de Arte Mayor (No. 22197, de los primeros días de Abril de este año), que son las partes primera y segunda de aquella obra. Le envié también en abril de 1945 dos números de la revista "Atenea", con colaboraciones mías. Y le escribí cartas en abril del $45 \mathrm{y}$ en septiembre. En casi dos años no he recibido, pues, noticias de usted. $\mathrm{Y}$ esto, no sólo me alarma, sino que desalienta mis energias ya escasas.

¿Acaso mis trabajos no han correspondido a las expectativas que usted cifraba en ellos? Podría ser. Y sería muy natural, después de tan larga espera y tanta conversación al rededor de mi larguísimo laborar.

Tampoco me ha acusado recibo siquiera el Prof. Morley, su maestro, y persona de tanto prestigio merecido.

Mi salud, particularmente me refiero a mis ojos, siempre amenazados, no me abandona del todo; y hasta me he acostumbrado algo a no sentir temor de la ceguera.

Deseo que sus trabajos, métricos o históricos, sigan cautivándola; y que goce usted de perfecta felicidad en compañía de sus chicas y de su esposo. Y la saluda respetuosamente su $S$.

\section{J. Saavedra}

Olvidaba decirle que en la obra Historia de la Literatura Nacional Española en la Edad de Oro por Ludwig Pfandl, trad. del Dr. J. Rubió B., Barcelona, Gili, I933, p. 676, hay datos para su Bibliografía de la versificación. Si usted reimprime tan útil folleto, yo podría darle algunas otras noticias, quizá. 
Prof. J. Saavedra Molina

Solar 0385 , Sector II 4

Santiago, Chile

I6 Octubre I946.

Muy apreciada señora Clarke de Shadi:

Recibí con gran atraso su carta del 26 de junio y tápidamente la del $x^{9}$ de septiembre. Gracias por ambas y mayormente por la segunda, tan cordial, en que, además, me honra con el envío de dos simpáticas fotografías, como adivinando mi gran deseo de ligar mis imaginaciones y recuerdos a apariencias más concretas que las simples palabras. Sus tres retoños forman un grupo encantador. Arte demostró el fotógrafo al arreglar el conjunto y elegir el momento de fijar la imagen, que es como fijar el tiempo, tan volandero. Al centro de la otra fotografía, excelente también, veo un caballero que juzgo ser un pariente de la misma sangre de usted. El joven del extremo, que le hace a usted pareja, ha de ser el Sr. Shadi. Moreno, me parece, como su hijita menor, y apostaría yo que tiene algo de "latino". Su chica mayor mira como el caballero del centro. Como usted ve, he pasado largos ratos tratando de adivinar los lazos familiares. - Voy a ver modo de que mi hijo mayor (34 años, médico), que es aficionado a la fotografía, me tome una, para retornarle su delicada atención; ojalá que consiga hacerlo en compañía de mis nietas.

Gracias todavía por haber gastado su tiempo en traducir mi "Confesión" (soneto "con estrambote", como escribieron los clásicos: Cervantes, Quevedo, ...). Parece que hay unanimidad en aprobar esa composición $\mathrm{y}$ en preferirla a las otras. Yo la prefiero también y por esto le di el primer lugar. ¿Qué podría decir yo, que apenas leo el inglés y que nunca he compuesto ni siquiera una carta en su caprichoso idioma, tan hermoso al mismo tiempo, sobre la propiedad de la traducción? La he leído y repetido con gran placer, admirando la fuerza y concisión con que el inglés puede expresar ciertos matices del pensamiento. $\mathrm{Ni}$ ¿qué falta hace para una persona como usted, que lee hasta el castellano arcaico? - ¿Permiso para publicarla? - Claro que lo doy, si fuese necesario. Pero no lo es, porque una traducción en verso es, hasta cierto punto, obra original. Por lo menos, traducir al castellano poemas del inglés sobre todo, o del alemán, es re-crearlos. Y el trabajo inverso ha de ser igualmente difícil. Cuando acaben de imprimir otro trabajo que está en prensa, en que mi 
amigo argentino Dr. J. F. Ibarra me explica sus sudores para traducir las Odi barbare de Carducci, encontrará usted mejores razones que las que acabo de darle.

En efecto, el motivo porque no pude escribirle a usted no bien recibí sus cartas fue que tuve que dedicar los cortos ratos en que puedo hacer trabajar mis ojos a la corrección de pruebas de dos artículos de los Anales, que espero hacerle llegar antes de que termine el año: uno se reficre al Eneasilabo, Tredecasílabo y Endecasílabo, el otro es una ampliación y corrección del de 1935 sobre los Hexámetros.

Gracias, en fin, por su reseña sobre mis estudios del Arte Mayor y del Octosílabo para la Hispanic Review. Su buena opinión me reconforta. Esperaba que me dieran alientos tres o cuatro personas de los Estados Unidos, entre las 9 ó ro a las cuales envié mis publicaciones. Sólo usted ha correspondido a mis expectativas; pero esta única vale por todas, pues usted, por las palabras que me dice, me saca de la gran duda en que yo estaba, a saber: ¿Será comprendido esto que explico como yo lo entiendo? -No sé si con la frase anterior diga algo claro para usted. El lenguaje es un medio dos veces reflejo de transmitir el pensamiento: primero a signos psicológico-auditivos, después a signos visuales lingüísticos (en realidad, el proceso es más complejo aún). Cuando hablo, y sobre todo cuando escribo, me pregunto siempre, pues, ¿estoy diciendo algo comprensible? -No sé si haya personas que se engañen de veras sobre el valor de lo que escriben. Yo no me he engañado nunca, me parece, acerca del poco o mucho que he atribuido a mis publicaciones. Pero, con una reserva: la de encontrar lectores que, con capacidades semejantes a las mías y honestidad semejante, puedan coger el mismo asunto bajo la misma luz. Esto exige similitud psicológica, intelectual y sentimental. Tal coincidencia es un milagro. Por consiguiente, sabiendo y todo que yo habia hecho buen trabajo, dudaba encontrar pronta comprensión. Sólo un técnico, como usted, puede valorizar cuánto hay de novedad en las teorías que implican mis estudios, teorías que ya están expresadas, fragmentariamente, y en desorden; y que mi estudio llamado Teoría no hará más que ordenar y completar.

Esperaba una buena carta del Prof. Morley, que no he recibido.

También del Prof. Leonard, que no ha podido escribítmela. ¡Cuánta pena he tenido al recibir una carta de su esposa, en que me acusa recibo de mis libros, y me hace saber que tan gentil persona falleció! ¡Con qué impaciencia esperé yo la publicación de mi Arte Mayor, pensando en él, haciéndole justicia, a mi parecer! Se fue sin la satisfacción de que alguien entre la gente castellana había apreciado su trabajo.

Todo porque son muy pocas las personas en el mundo que entienden 
y se interesan por una ciencia que es a los versos lo que la teoría musical es a la música. Usted, que en compañía de sus tres pequeñas artistas, gusta de la música, está capacitada doblemente para entender lo que digo.

No conozco la obra de que me habla: "Professor Morley's recent chronological list of early ballads". ¿Dónde se publicó?

"I am on vacation until September", añade usted. Luego, usted ihace claśes tal vez? ¡Qué poco sé yo de usted misma! Si profesora es, entonces, somos dos veces colegas; eso sí, ¡con qué diferencia de tiempos!

De España me escribió D. Ramón Menéndez Pidal felicitándome por mis publicaciones y anunciándome que allá se va a dar noticia de ellas. En Buenos Aires y en Montevideo han tenido también buena acogida. En Chile no se ha escrito sobre ellos (¿Quién podría hacerlo?); pero he recibido las felicitaciones "de rigor" por parte de personas que me quieren bien, y que quizá lamentan que haya dedicado tanto tiempo y trabajo a cosas tan inútiles.

Una carta del Profesor Mapes (de Iowa) recibí hace poco en que se queja también de haberme escrito varias cartas que no han llegado a mi poder, ni de haber recibido las mías; por lo cual me creía muerto o ciego desde hace ya mucho tiempo. ¡Loado sea Dios, que me conserva vida y vista!

Por primera vez he recibido con su carta del $I^{\circ}$ de Sept. la traducción "Confession". Puede creerme que no habría dejado de agradecerle pronto semejante delicadeza si antes hubiese tenido conocimiento del hecho.

Gracias aún por la noticia de que el Profesor Morley recibió mis envíos y que los aprecia.

Su bondad me anima a pedirle un servicio de orden semejante. El Prof. G. Dundas Craig me escribió por última vez el 29 de diciembre de 1945. Me decía entonces: "I have had another spell of arthritis ..." Le remití yo en abril "El Arte Mayor" y una carta, no certificados. No he recibido respuesta y él nunca ha dejado antes de contestarme cuando tecibe algo. ¿Le sería a usted posible saber cuál es el estado de su salud? El Prof. Craig vivía en 25I4 Haste Street, Berkeley, 4, California.

Reclámeme usted datos para su Bibliography en cuanto los necesite. No los envio hoy porque tengo que buscarlos entre mis apuntes.

Sus Notes on Villasandino's Versification son excelentes. Las he celebrado por muchos motivos. Desde luego, la elección del poeta, que tiene más don poético que muchos de los otros: emoción, gracia, musicalidad... Después, observaciones que creo que nadie ha hecho antes de usted. Y en fin, penetración en el arte mayor que iba derecha a las mismas conclusiones a que llegué yo. Lo que en usted, joven y extranjera, es más meritorio 
que en mí. Para mí, pues, ha sido satisfacción y garantía de no haber errado. Es una calamidad que mis ojos me hayan privado (hasta aquí) de colaborar con usted en algún trabajo métrico. Usted dispone allí de libros y revistas que aquí no existen, tal como en Alaska, supongo. Cuando se vive en un centro de cultura superior, con toda clase de recursos, no se sospecha la nostalgia de sentirse en una isla desierta, como Robinson, o en un páramo, como los personajes de ciertos cuentos de Alaska o de la Tierra del Fuego.

Nunca recibí ejemplares de la Pacific Frontier de que usted me habla. Gracias siempre. $Y$ también por su of recimiento de traducir al inglés posibles colaboraciones mías. No entiendo en eso mucho más que cualquier persona. El problema de las razas, tan candente en otras regiones, aquí no se conoce. El europeo se mezcló aquí con el indígena y nada más. La constitución étnica de Chile es, por lo mismo, muy sencilla. Abajo, quiero decir, entre las gentes menos ricas, o más pobres, que sería más exacto, mestizos y unos pocos restos araucanos que van blanqueando con los nuevos cruzamientos. Arriba, blancos y mestizos blancoides. El tipo rubio abunda. Yo fui rubio en mi niñez; mi mujer también; y tres de mis cuatro hijos ( $\mathrm{El}$ segundo murió de año y medio). Mi yerno es rubio, y más que todos nosotros ( $\mathrm{Su}$ madre es alemana nacida en Chile). Mis nietecitas son ambas rubias, y la mayor una verdadera "bárbara germánica". Aquí no hay negros ni mulatos ni amarillos. En el Perú sí, porque el virreinato fue pueblo en que abundó la riqueza. Pero Chile fue siempre país de "rotos", aventureros de espada en una mano y la cruz en la otra, que al fin se organizaron en sociedad, mezclándose con los indígenas, a los cuales van "digiriendo" poco a poco, después de cada generación. Chile y Argentina serán en un siglo más países exclusivamente blancos. Claro es que nadie puede predecir lo que vendrá en el Pacífico cuando chinos y japoneses y malayos compitan con los blancos.

El signo racial, cabellos rubios, propio de germánicos y nórdicos más bien que de mediterráneos, es más frecuente que los ojos azules; pero ni el uno ni el otro duran hasta la edad adulta en muchísimos casos. Yo lo perdí a los diez o doce años, mi mujer a los 30 ó 35, mi hija a los 20, si bien algo le queda. Mi hijo menor, de chico era un patito, y ahora a los 25 años tiene cabellos negrísimos. Parece que el clima, con ser templado y más bien frío, no es propicio a ese rasgo racial. Los juicios políticos que se basan sobre rasgos raciales son, por esto, si no hubiese otras razones, precipitados.

América del Sur es un enorme crisol en que a ojos vistas se verifican cosas maravillosas en tales materias. Conocí el Brasil a principios del si- 
glo; era un país de raza mestiza y mulata, en que los negros se veian con más frecuencia que los blancos. Estuve otra vez en r930; era ya un país más bien blanco, en que éstos habian "digerido" al africano. Por esto, yo creo que los blancos de Estados Unidos hacen muy mal en no "digerir" al negro, cuanto antes, para acabar con ese grave problema, para ustedes. Si no, a la larga, puesto que ellos se multiplican con gran fecundidad, los Estados Unidos van a ser estados negros. Tal vez me equivoco, por falta de datos.

Le devuelvo a usted su carta de la Hisp. Review. Cuando reciba las copias pertinentes, le agradecería el envío duplicado.

Le remito certificada mi Bibliografía de Rubén Dario; y dentro, dos hojas de erratas, para El Octosilabo y para El Arte Mayor. De esta Bibliogrinfía la tirada es muy corta, 300 ejemplares, y me dieron sólo unos pocos. Van a escasear muy pronto.

Cariños para sus tres artistas, y saludos para usted en compañía de su esposo, de parte de su colega y servidor.

J. Saavedra

I8

Santiago, Chile, I Abril 1947.

Muy apreciada señora Clarke de Shadi:

Aunque no he recibido respuesta de usted a mi carta del I6 de Octubre último, sé que la recibió, porque el Prof. Dundas Craig me escribió diciéndome que una señora había preguntado por teléfono por la salud de él, desde la Universidad, por encargo mío.

Ahora le escribo solamente para cumplir mi promesa de enviarle una fotografía de mis nietecitas en mi compañía, y para anunciarle el envío de un nuevo paquete de libros, certificado (No. 23968), el 29 de Marzo recién pasado.

Van en el paquete: "Tres grandes metros: el Eneasillabo, el Tredecasílabo, y el Endecasílabo" (libro que continúa la serie de El Octosílabo y de El Arte Mayor); "La versificación neoclásica" (que complementa la monografia anterior Los Hexámetros castellanos); y un folleto que debió aparecer como reseña bibliográfica, pero que le dieron importancia de artículo, sin intención mía. 
Después de la publicación de lo que dejo enumerado, me queda un resto de manuscritos sobre dos temas, pero algo incompletos y desproporcionados, por haberles sustraído para los ya publicados ciertos pasajes. Tendré, pues, que trabajar un poco en "Historia de las ideas métricas" y en la Teoría, que es una síntesis de interpretaciones generales de las varias investigaciones ya declaradas. ¿Podrán mis ojos amagados hacer ese trabajo? Es lo que me pregunto.

También trabajo en un Manual, que me parece más necesario que los estudios doctrinales. Pero, no más de media hora cuando logro un día de buena visión.

Deseo salud, felicidad y alegría para usted, sus hijitas y su esposo, y que todos acepten mis buenos augurios de hoy.

J. Saavedra

I9

Santiago, Chile, I6 Julio I 947.

Muy apreciada señora Clarke de Shadi:

No he recibido ninguna carta suya después de la del $I^{\circ}$ de septiembre del año pasado. Estoy temiendo que alguna se haya perdido nuevamente.

Yo le escribi a usted el 16 de octubre del 46 y el $I^{\circ}$ de abril del presente año. Esta última fue certificada bajo No. 23455 y contenía una fotografía.

Además, el 29 de marzo último le despaché un paquete con dos libros y un folleto, certificado bajo No. 23968.

Mi salud (mis ojos) se mantienen medianamente y hasta han mejorado un poco con el uso de vitaminas; pero no he podido aprovechar estas ventajas porque ahora el pais está más enfermo que yo y que nunca. La carestía de la vida es mucha y la escasez de alimentos, vestuario y habitaciones también. Tenemos poco carbón (invierno con frío), poca energía eléctrica, y ambos suministros están racionados: no hay gas desde medio día hasta el anochecer; ni luz artificial, ciertos días, antes de las 8 ó 9 de la noche. ¿Cómo trabajar en cosas de escritorio, en tan incómodas condiciones? 
Deseo que usted, su esposo, a quien saludo, y sus hijitas estén bien y felices; y acepte usted los buenos augurios de su servidor y colega.

J. Saavedra

20

Prof. J. Saavedra Molina

Solar 0385

Santiago, Sector II4, Chile.

26 Sept. 1947.

Muy distinguida señora Clarke de Shadi:

Con gran alborozo recibí su carta del I5 de agosto, tan cordial y tan llena de buenas noticias. Me quedé esperando la llegada de las "copies" de su artículo sobre mi Octosílabo. Aunque sé, por su buena carta anterior, que usted me trata con bondad, estoy impaciente por leer su reseña. Pero no llega todavía. Y no quicro dilatar más mi agradecimiento. Quisiera que los tiempos fuesen los del siglo xvil para escribirle que "me pongo a sus pies". Las costumbres de hoy son menos expresivas, pero quizá más sinceras.

Le remito por correo ordinario dos libritos de escaso mérito, simples curiosidades para su biblioteca: uno de 1815 y otro de 1826 ; como usted ve, apenas un poco más viejos que yo, que nací en 1880 .

Acepto con gusto su of recimiento de mandarme dos ejemplares más de su reseña; y reciba desde luego mis gracias.

Un amigo argentino, que está actualmente en Génova (Italia), me acaba de escribir lo siguiente: "De sus libros de métrica no me atrevo todavía a hablarle con la seriedad debida a una obra única en nuestra lengua por la profundidad de la doctrina, la originalidad de la concepción, la erudición puesta al servicio de un juicio certero, y la inmensa labor de benedictino que representa" - ¿Qué más necesito yo sino que los amigos me aprueben?

El crítico uruguayo que se firma Lauxar (pseudónimo de D. Osvaldo Crispo Acosta), que yo no conocía antes sino de nombre, me dice, con fecha 4 de agosto: "Hace tiempo estoy por escribir a usted para decirle 
mi admiración, y más que admiración, mi asombro, por los trabajos lite. rarios que tuvo usted la amabilidad de enviarme (a pedido de él). No los he leído todavía todos; pero he visto de ellos más que bastante para tenerlo a usted por maestro excepcionalísimo en estudios literarios. . . Todo me interesa en lo que he leído, y sobre todo, lo relativo a la métrica. Parece que Chile hace de esa materia una especialidad. A las obras de Bello y de La Barra úno yo ahora, entre mis libros, los de usted. No sé qué haya en español que pueda ponerse al lado de esos trabajos".

Lamento que Lauxar no cite también a Hanssen, mi maestro de latín. No fui discípulo de él en otras materias, directamente, pero sí de modo indirecto, leyendo sus trabajos. $Y$ era un maestro inolvidable.

Sé lo que es edificar y las molestias que ocasiona. Espero que usted y los suyos estén disfrutando ya de las comodidades de las nuevas habitaciones añadidas a las antiguas. En compañía de sus chicas, tan "simpáticas", como aquí decimos, para expresar no solamente lo que los españoles dicen "guapas", sino más bien la gracia, la atracción bondadosa y afectuosa.

Acepte, Señora, mis votos por su felicidad personal y los saludos de su servidor.

J. Saavedra

Santiago, 6 Dic. I947,

Muy distinguida señora Clarke de Shadi:

A mi carta del 26 de Septiembre tengo ahora que hacer una enmienda: recibí los seis ejemplares de su reseña sobre mi Octosílabo, que leí con mucho agrado y agtadecimiento: ha sido la más extensa y mejor fundada de las reseñas que he leído hasta ahora. Por todo lo cual le expreso mi agradecimiento.

Además del paquete con dos libritos impresos en España, que le remití en Septiembre, le envié últimamente un folleto sobre Gabriela Mistral, su vida y su obra. Espero que le llegue, sin pérdida. Digo esto porque no fue certificado. 
Me imagino que ya está usted gozando de las nuevas comodidades de su casa, en compañía y con la felicidad de los suyos, a quienes saludo juntamente con usted.

Soy atto. S. de Ud. y su colega afmo.

J. Saavedra

Julio Saavedra Molina

Solar 0385 , Santiago, Chile.

6 Septiembre 1948.

Distinguida Sra. Clarke de Shadi y apreciada colega:

Gracias por su carta del 2 de agosto, por su nueva monografía sobre las estrofas del s. xv, y por los numerosos ejemplares de su reseña, tan bondadosa, sobre mi Arte Mayor. Su deuda ha sido pagada con creces, y estoy un poco avergonzado de la zozobra que me produjo su prolongado silencio de un año (Su carta anterior fue de agosto del 47). En ese tiempo le envié yo dos paquetes: uno con dos libritos españoles, de I8I5 y I826, meras curiosidades métricas; y el otro con un ejemplar de mi ensayo Vida y obra de G. Mistral; y dos cartas: del 26-IX-47 y del 6-XII-47. Me di pues a pensar que le habría ocurrido a $U d$. alguna de esas desventuras que nos envía de repente el destino. Le escribi entonces al Prof. Morley rogándole me comunicase noticias de Ud. Al Prof. Dundas Craig no le pedí noticias, sino que le hablé de mi zozobra en relación con la muerte del Prof. Leonard y las noticias de otro profesor de Wisconsin que él me daba. Bueno; asunto pasado y sellado.

Con el Prof. Leonard se me quedó suspenso y pendiente un diálogo epistolar, para continuarlo en los Campos Elíseos. El tema del diálogo se lo propongo ahora a Ud., en relación con los renglones finales de su reseña sobre el Arte Mayor (p. I75), y su invitación a estudiar la métrica del Cid; esto es: que, sin un conocimiento de la música con que se cantaba este poema, los modernos no estamos capacitados sino para hacer conjeturas acerca del metro (pp. I4-I7 de mi Arte mayor). Es claro que el enigma de la métrica del Cid es un desafío a los investigadores, e incita a abordarlo; pero prevalece, en mí; la convicción de que el metro estaba 
en la música, y de que lo que refleje la "letra" puede ser tanto $2+2$ como $3+3$ como $4+4$, y la duda no se resolverá sin conocer el movimiento o compás de la música.

Pedro Henriquez Ureña era gran trabajador y erudito, pero, como muchos otros, cayó en la trampa: olvidó que el metro en las canciones lo fija la música y se dio a divagar en su libro La versificación irregular sobre cosas irreales. Otros cayeron en la trampa del prejuicio silábico y se aplicaron a restaurar los viejos versos según el silabismo de los clásicos de los siglos xvI al xviri. Hay que evitat estos dos escollos, me parece a mí.

En páginas escritas para mi Teoría distingo más detalladamente que en el Octosilabo (Pp. 28-29 y 89) o en el Arte mayor (Pp. I5-I6) la existencia diferente de cuadro musical (metro, cadencias, ritmo) y verso (letra, lenguaje, sílabas). También me refiero a eso en Tres gr. metros y en la Versif. neoclásica, pero de pasada. En las canciones, desde la Iliada hasta una tonada o un tango, el cuadro musical (movimiento o compás) lo da la música, mientras la letra o el baile se ajustan a dicho cuadro; pero en los poemas de lectura el cuadro musical va incluido y oculto en la letra y tiene que discernirlo el lector. No se deben considerar pues en el mismo plano las "letras" y las "lecturas"; ni en las letras inferir el cuadro musical como si estuviese también oculto en las palabras; al menos sin grandes reservas y precauciones.

Cuando el verso para la lectura es métrico, es decir, cuando cada renglón del poema se ajusta a una medida prevista (igual número de acentos rítmicos, con o sin igual número de sílabas), la lectura musical (acompasada, métrica, rítmica) es fácil y se hace adecuadamente de buenas a primeras. Pero cuando el verso para la lectura es amétrico (renglones cortos de Whitman o de Amy Lowell, "verso libre" de los simbolistas franceses o de los modernistas castellanos) la lectura musical no es fácil siempre, porque el poeta a menudo desdeñó acompasar las palabras, re. huyó las cadencias, y el lector no dispone de más guia musical que su buena voluntad para sacarlos de la categoría de la prosa.

No hay que confundir, pues, como tan bien lo hizo notar el Prof. Morley en Recent Tbeories..., ni considerar iguales el verso libre (amétrico) y las letras de canciones, cuyo metro está en la música con que se cantan; irregulares pues de diverso modo y por diferente causa.

El Cid no es amétrico sino para el lector moderno, que ignora su música y le da un uso inadecuado a su composición. Su metro, su cuadro musical o compás, pudo ser de 4 y 4 acentos, como creyó el Prof. Leonard; de 3 y 3, como creyó Delius, cit. por el Prof. Morley, o de 2 y 2, como 
piensa Ud. No abordo yo este tema en el resto de mi obra; pero pienso, sin embargo, como Ud., que es más natural suponer que el $C i d$ se cantaba en un cuadro musical de $2+2$ acentos rítmicos principales, en atención a que todo el resto de la versificación castellana (que es como decir "el oído castellano") se ajusta al movimiento de 2 ó de $2+2$.

Lo he dicho en mi Oclosílabo con referencia a los versos $7 / \mathrm{r}, 3 / \mathrm{r}$, 7/I-7/r, cultivados silábica o rítmicamente; en mi Arte mayor con referencia a los versos $5 / \mathrm{I}, 5 / \mathrm{I}-5 / \mathrm{r}$, adónico y adónico doblado; en mis Tres gr. metros con referencia al $8 / \mathrm{I}, 4 / \mathrm{I}, \mathrm{I} 2 / \mathrm{I}, 6 / \mathrm{I}$ y $\mathrm{IO} / \mathrm{I}$ o endecasilabo, el cual por su longura muestra mejor que los otros el juego de dos acentos rítmicos principales y de otros subordinados a ellos. Y lo diré también, si la salud me acompaña, en un estudio del alejandrino $6 / 1-6 / 1$, en que no repito lo que dijeron autores como Marasso o Henríquez Ureña, sino que amplío y confirmo lo que pensaba Hanssen al fin de su carrera y expresó en Sobre el metro del Poema de Fernán González, x9o4, en consonancia con el arte mayor y el octosílabo, a saber, que el alejandrino se cultivó de dos modos en el período arcaico: "por sílabas contadas" (cuya cuenta cabal a veces cuesta hallar) en el Poema de Alexandre, los de Berceo, y quizá algún otro; y "por sílabas NO contadas" en el Poema de Fernán González, el de Juan Ruiz y el del Canciller Ayala, para no citar obras menores o inadecuadas por ser canciones; pues en estos grandes poemas, todos para la "lectura", se mezclan no sólo alejandrinos con octonarios, como dijo Hanssen, sino hemistiquios que frecuentemente oscilan de $6 /$ i a $5 / 1$ y a $7 / 1$, y hasta más.

El alejandrino de los poemas mencionados no se diferencia pues del arte mayor ni en cuanto a la cesura ni en cuanto a la oscilación silábica, sino en que el verso tipo es $6 / \mathrm{I}-6 / \mathrm{I}$, par, en este caso, y $5 / \mathrm{I}-5 / \mathrm{I}$, impar, en el arte mayor. El $5 / \mathrm{I}-5 / \mathrm{I}$ muestra más fácilmente la acentuación 2 + 2 y el cuerpo central áxxá; el $6 / 1-6 / 1$ menos fácilmente la acentuación $2+2$ y el cuerpo central áxxxá, porque a veces el poeta pone una palabra con acento de sentido (gramatical) entre los vértices, los cuales se presentan así: áxírá (quizá sería mejor representar este hecho de este otro modo: áxaxá), y en este caso la acentuación tiene la apariencia yámbica, de $3+$ 3: xá xa xá $(x)$... Creo que no es necesario copiar aquí versos para ejemplo. Se hallan, a todo el largo de dichos poemas, hemistiquios, sin sinalefas ni hiatos posibles, en que la cuenta da $7 / 1$ o $5 / \mathrm{I}$, y a veces el verso $\sin$ ningún hemistiquio $6 / \mathrm{x}$.

Es decir (y ahora entro en una reflexión general que iba dejando para el artículo dedicado especialmente a la Teoría), el desarrollo histórico de la o las técnicas versificatorias del castellano me lo represento yo 
como un procedimiento que fue, hasta el s. $\mathrm{xv}$, principalmente rítmico (acentual, prefiere decir el Prof. Morley), moldeado en cuadros musicales o acompasado en movimientos de 2 acentos o de $2+2$ (sin contar los otros acentos rítmicos subordinados a los principales). Durante ese petíodo el "cuento de sílabas" o "silabismo" fue una novedad que empezó con Berceo y Juan Lorenzo (Alexandre) a horadar la roca primitiva, natural, popular, y siguió muy de lejos con Santillana, Gómez Manrique, y demás "cortesanos"; y sólo se sobrepuso al "ritmismo" con Boscán, Garcilaso, etc., y no desapareció sino con Quevedo, para renacer con R. Darío (y aun antes, en casos menos decisivos, con Ric. Palma). Pero, ahora, con los papeles trocados; porque en el siglo actual predomina el silabismo de los clásicos, no en competencia con el ritmismo decaído (técnica más bien excepcional en castellano), sino en competencia con el ametrismo (o verso libre). A este tema: el Verso Libre, le dedico también otro artículo, que aguarda igualmente la salud de mis ojos para ponerlo en condiciones de publicación.

Omití en la hoja anterior hacerle notar que "el cuerpo central" axaxá pertenece sólo a los hemistiquios de acentuación llamada yámbica, que son menos frecuentes, me parece, que los de acentuación anapéstica los cuales

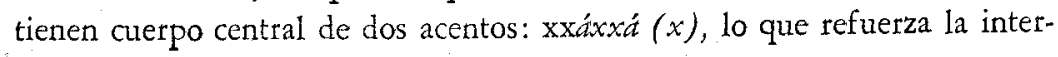
pretación de $2+2$.

Toda esta materia estuvo organizada, redactada juntamente con la que Ud. ya conoce, y hasta con índices alfabéticos, en I94I, como se lo dije alguna vez. La imposibilidad de publicar mi obra total me obligó a descuartizarla, a llevar pasajes de un lado para otro, a fin de convertirla en artículos para los ANALES. Han quedado sobrantes desperdigados con que trato de hacer nuevos artículos, pero no sé si encontraté fuerzas para darles remate algún día. Además, con el tiempo, me he puesto más exigente. Tal como tengo apuntalados los pasajes sobre los fundamentos psicológicos del ritmo en el lenguaje no me satisfacen. Los psicólogos profesionales ayudan poco en sus grandes libros. Titchener es uno de los mejores. Materia obscura que me exige revisar muchos libros leídos otrora y semi olvidados hoy.

$\mathrm{Si}$, pues, Ud. quisiese que esta fuera la obra o artículo en colaboración que hace años me propuso que escribiésemos, yo le pediría que compusiese un artículo en que entraran (en castellano o traducidos al inglés) los pasajes que $U d$. juzgase dignos de figurar en su artículo. Yo no tengo esperanza cierta de publicar nada próximamente. Puedo, con malestar a 
los ojos que se traduce en congestión y confusión de ideas, escribir una carta como ésta, no dictada a nadie. Pero leer, anotar, investigar, como antes,...

Leyendo su artículo Miscellaneous str. F., $\tan$ bien informado de cuanto se ha dicho sobre esos temas: leyendo las publicaciones del Prof. Morley, mido la distancia que va de investigar en Chile a hacerlo en California. ¡Cuántas publicaciones que no conozco ni podré conocer! ¡Cuánto que adivinar aquí, por lo mismo, más bien que estudiarlo y controlarlo!

Como todos los suyos, este artículo me parece muy útil. Algo nuevo he aprendido en él, y he visto con mayor claridad cosas ya sabidas. Es un buen complemento de sus artículos anteriores sobre el s. XV. ¿Por qué no escribe un ensayo de conjunto: "Panorama de la versificación en el s. xv?"

Es claro que Ud. al decir (P. I53): "The SERRANILLA, made famous by the Marqués de Santillana, was one of the most popular of the minor strophes. Its chief characteristic is its rhythm, the line employed being the quebrado of the verso de arte mayor, ..." no ha querido decir ninguna de tres cosas que yo entiendo o creo entender: que Santillana fuese el primero en escribirlas (puesto que Juan Ruiz incluyó "canticas de serrana" en su Buen Amor); que muchos poetas imitasen a Santillana; que Santillana usó solamente el quebrado, o mejor, el adónico, o mejor, el hexasilabo $5 / \mathrm{I}$ (puesto que siete de las diez las compuso en $7 / \mathrm{I}$ y las tres en $5 / 1$ no of recen ninguna hipometria ni hipermetría).

En inglés, strophe, ¿tiene el sentido de "composición" o poema? - "Estrofa", en castellano, no puede usarse en vez de "serranilla", sino de una parte de ella o sección rimada de pocos versos cuyo orden se repite.

Me parece haber leído en un artículo de Menéndez Pidal que la serranilla castellana cs imitación de un género semejante del francés, común a varios países de la Edad Media.

Revisando sus opúsculos, he advertido que yo habría ganado mucho con conocer a tiempo su AGUDOS and ESDRƯJULOS... al hablar de ese tema en mis Tres gr. metros, hacia el fin. El cambio de casa que hice en 1942 desconcertó mi trabajo.

Con motivo de su Miscellaneouts..., he revisado (a la ligera, pues mis ojos no me permiten larga lectura, sobre todo de tipografía pequeña o minuciosa) el art. del Prof. Morley sobre el Cid. ¡Qué de cosas sabe él que yo ignoro! Me interesa mucho la obra en que, me dicen, está empeñado: ordenación y edición del Romancero. ¿Es verdad? 
Celebro, pues, haberle ayudado con mi Octosilabo, y sobre todo haber dicho y tal vez probado otra cosa que Jaimes Freyre, quien lo indujo en error (p. 970).

Me interesa también mucho la obra futura de Ud, en métrica. ;Son tan pocos los que se ocupan en métrica y menos aún los que llevan buena orientación! Si Ud. no empuña el estandarte nadie lo va a sostener.

Le comuniqué en carta anterior opiniones manifestadas en cartas por varias personas. He aquí otra, del Prof. Guillermo Díaz-Plaja, de la Universidad de Barcelona: "Su trabajo sobre el octosílabo-precioso trabajo-lo vi por primera vez en casa de D. Arturo Marasso... Conceptúo a Ud. como el primer técnico en versificación española. Su obra es, en este sentido, definitiva". Pero, sólo Ud. la ha reseñado en revistas. Yo no sé de otras, salvo unas cuantas líneas en diarios de aquí y en la REV. HISP. MODERNA de N. York.

Respondo a su pregunta. La escasez de combustible de este invierno no fue como la del pasado 1947. El 47 faltó el carbón de piedra (de Arauco) a causa de las huelgas de mineros en esa región, lo cual afectó a la producción de gas y de electricidad. Hay que saber que aquí no son muchos los que consumen electricidad en calefacción o cocinas, ni muchos los que consumen gas, y que el pueblo, los pobres, consumen carbón de madera o artificial. Pues bien, este año faltó el carbón de madera; y a causa de desperfectos en las instalaciones productoras faltó también la electricidad. Pero, en general, falta todo: alimentos, ropas, medicinas, etc. porque sobran los malos ciudadanos que practican la especulación y porque el Gobierno no impide enérgicamente la compra en el extranjero de objetos de lujo; de suerte que las divisas (valores extranjeros) escasean o faltan para comprar lo más necesario, para el pueblo.

Ahora quiero yo saber dos cosas. En California, chabla el castellano alguna parte del pueblo? ¿Se oye esta lengua con frecuencia?

Otra: ¿Está situado El Cerrito cerca de Berkeley? ¿Está en la bahía de San Francisco? No he podido establecerlo mirando mapas.

Lo que me dice sobre el empeoramiento de las comodidades en California no me extraña: la vida es peor ahora en todas partes que antes de la última guerra, y entre las dos guerras peor que a principios del siglo. Conclusión: al pueblo no le convienen las guerras.

Pero, nosotros hemos sido afectados sin haber tenido guerra y por no haber sabido aprovechat el tiempo de bonanza.

Su curso sobre el drama español en los siglos XIX y xx ¿lo desatrolla Ud. en la Universidad? 

belleza.

Celebro que sus simpáticas chicas progresen en música y... en

La mayor de mis nietecitas tuvo este invierno una fuerte "grippe" (un resfriado con fiebre) y ha quedado, según parece, con pielitis (infección en los riñones o en la vejiga). Está en tratamiento médico. Su ánimo es bueno, sin embargo. Tiene ésta cinco años y medio y la menor $4 \mathrm{I} / 2$. Son bastante inteligentes; pero aún no van a la escuela, si bien la mayor ha aprendido algo a leer, sola.

Su explicación sobre el uso de los nombres es completa. Pero, ¿es correcto poner en los sobres de mis cartas: Mrs. D. C. S., por ejemplo? -Le deseo felicidad y acepte, distinguida colega, mis saludos respetuosos $y$ afectuosos.

J. Saavedra

23

Santiago, 22 Dic. I948.

Distinguida Sra. Clarke-Shadi y apreciada colega:

Muy agradecido le estoy del obsequio de su libro "Romance Literature" y los incontables ejemplares de su reseña sobre mi "Arte Mayor", que ya le agradecí en carta por avión del 6 de septiembre. Su libro me ha llegado como un bello aguinaldo para esta Navidad que se avecina; que yo les deseo felicísima a Vd. y a los suyos, como también el Año Nuevo.

Su idea de considerar en un solo bloque las literaturas neo-latinas (¿Por qué no también la provenzal-catalana?) concuerda con la de grandes lingüistas y filólogos alemanes, que han discurrido sobre las lenguas románicas en conjunto. $\mathrm{Y}$ puede ser muy apreciada en los Estados Unidos, donde es frecuente que quien sabe francés sepa también castellano e italiano. Sin vivir yo allí, aprecio también mucho su idea; y he sentido novedad y agrado al encontrar juntos y haciendo camino paralelo a personajes históricos cuyas vidas y escritos la costumbre me había hecho ver muy distanciados, clasificados en mi memoria en orden diferente, quizá menos adecuado, $y$ movidos por otras reglas y resortes.

Y no sólo novedad y agrado encuen²ro, sino que los hechos literarios, 
así presentados, en un escenario más amplio, me sugieren reflexiones impensadas, sorpresivas, sobre influjos posibles, además de los que $\mathrm{Vd}$. indica.

Conocía libros de "literaturas comparadas", todas las europeas, pero demasiado sumarios e ineficaces en tal sentido.

La apariencia modesta de su libro forma contraste con los muchos estudios, conocimientos, y trabajo que supone la elaboración de su "Romance Literature". No ha reunido Ud. pedazos de mano ajena cosidos lado a lado. Algo hay, claro, que es repetición (bien elegida); pero, en general, se ve que Ud. ha leído las obras de que habla, y sabe lo que dice, y lo piensa por si misma. Es harto decir, porque su edad no es mucha y la materia en que se ocupa, vastísima, no obsíante ser lo más granado solamente de cada nación latina o de los autores considerados.

Aunque elemental y sin erudición, su libro enseña mucho, aun a los que ya dejamos el colegio, hace buen rato. Yo he aprendido no poco en su libro, o refrescado quizá. No he terminado todavía de leerlo; porque debo hacerlo lentamente, por mis ojos y para meditarlo.

No tengo reparos que merezcan señalarse, pues serían de orden, más bien editorial, que Ud. no ha podido, tal vez, remediar. ¿Conoce Ud. la "Histoire illustrée de la Littérature Françdise", précis méthodique par E. Abry, C. Audic, y P. Crouzet (Paris, Didier, I9r6)? O bien: ila Historia de la Literatura Española... por Guillermo Díaz-Plaja? Son 2 vol. de I942, con reimpresiones posteriores (Ediciones La Espiga, Barcelona)?

No hay papel para más. La saluda su afmo. colega 